\title{
Implications of a 3.472-3.333 Gyr-old subaerial microbial mat from the Barberton greenstone belt, South Africa for the UV environmental conditions on the early Earth
}

\author{
Frances Westall $^{1, *}$, Cornel E. J. de Ronde ${ }^{2}$, Gordon Southam ${ }^{3}$, \\ Nathalie Grassineau ${ }^{4}$, Maggy Colas ${ }^{5}$, Charles Cockell ${ }^{6}$ and Helmut Lammer ${ }^{7}$ \\ ${ }^{1}$ Centre de Biophysique Moléculaire, CNRS, Rue Charles Sadron, and ${ }^{5}$ Centre de Recherches sur les \\ Matériaux à Haute Température, 1D, avenue de la recherché scientifique, 45071 Orléans Cedex 2, France \\ ${ }^{2}$ Institute of Geological \& Nuclear Sciences, 30 Gracefield Road, PO Box 31-312, \\ 6315 Lower Hutt, New Zealand \\ ${ }^{3}$ Department of Earth Sciences, University of Western Ontario, London, Ontario, Canada N6A $5 B 7$ \\ ${ }^{4}$ Royal Holloway, University of London, Egham, Surrey TW20 OEX, UK \\ ${ }^{6}$ Planetary and Space Sciences Research Institute, The Open University, Milton Keynes, MK7 6AA, UK \\ ${ }^{7}$ Space Research Institute, Austrian Academy of Sciences, Schmiedlstr. 6, A-8042 Graz, Austria
}

\begin{abstract}
Modelling suggests that the UV radiation environment of the early Earth, with DNA weighted irradiances of about three orders of magnitude greater than those at present, was hostile to life forms at the surface, unless they lived in specific protected habitats. However, we present empirical evidence that challenges this commonly held view. We describe a well-developed microbial mat that formed on the surface of volcanic littoral sediments in an evaporitic environment in a 3.5-3.3 Ga-old formation from the Barberton greenstone belt. Using a multiscale, multidisciplinary approach designed to strongly test the biogenicity of potential microbial structures, we show that the mat was constructed under flowing water by $0.25 \mu \mathrm{m}$ filaments that produced copious quantities of extracellular polymeric substances, representing probably anoxygenic photosynthesizers. Associated with the mat is a small colony of rods-vibroids that probably represent sulphurreducing bacteria. An embedded suite of evaporite minerals and desiccation cracks in the surface of the mat demonstrates that it was periodically exposed to the air in an evaporitic environment. We conclude that DNA-damaging UV radiation fluxes at the surface of the Earth at this period must either have been low (absorbed by $\mathrm{CO}_{2}, \mathrm{H}_{2} \mathrm{O}$, a thin organic haze from photo-dissociated $\mathrm{CH}_{4}$, or $\mathrm{SO}_{2}$ from volcanic outgassing; scattered by volcanic, and periodically, meteorite dust, as well as by the upper layers of the microbial mat) and/or that the micro-organisms exhibited efficient gene repair/survival strategies.
\end{abstract}

Keywords: Early Mid Archaean; Barberton; microfossils; littoral zone; UV environment

\section{INTRODUCTION}

Calculated UV radiation fluxes to the early Earth's surface suggest that the DNA-weighted irradiance was up to three orders of magnitude higher than that present today (figure 1; Cockell 1999; Cockell et al. 2000). Without any attenuating factors, such a flux would have made the exposed surface environments of the early Earth hostile to life. The discovery of a microbial mat formed in an environment that was in the photic zone and at least episodically exposed (i.e. an evaporitic littoral environment), therefore has very important implications for constraining the UV environment at the surface of the early Earth.

\footnotetext{
* Author for correspondence (westall@cnrs-orleans.fr).
}

One contribution of 19 to a Discussion Meeting Issue 'Conditions for the emergence of life on the early Earth'.

\section{(a) The atmosphere and $U V$ radiation on the early Earth}

Many factors influence the flux of UV radiation through an atmosphere, including solar luminosity, planet obliquity, length of day, gaseous composition of the atmosphere and the presence of UV absorbers, such as dust, sulphur and organic hazes. The UV flux from the early Sun was higher than at present, especially at lower wavelengths (Canuto et al. 1982); indeed, XUV fluxes at $3.5 \mathrm{Ga}$ are estimated to have been six times those of present levels (Ribas et al. 2005). On the other hand, modelling of the evolution of main sequence $G$ stars shows that their luminosity would have been $25-30 \%$ lower in their early phases (the equivalent of the Hadean-Early Mid Archaean period on Earth; Newman \& Rood 1977; Gough 1981). This translates into $c a 35 \%$ less UV radiation in the $200-300 \mathrm{~nm}$ range (Zahnle \& Walker 1982). The shorter length of day on the early Earth (estimated at $c a 15 \mathrm{~h}$ for the period 


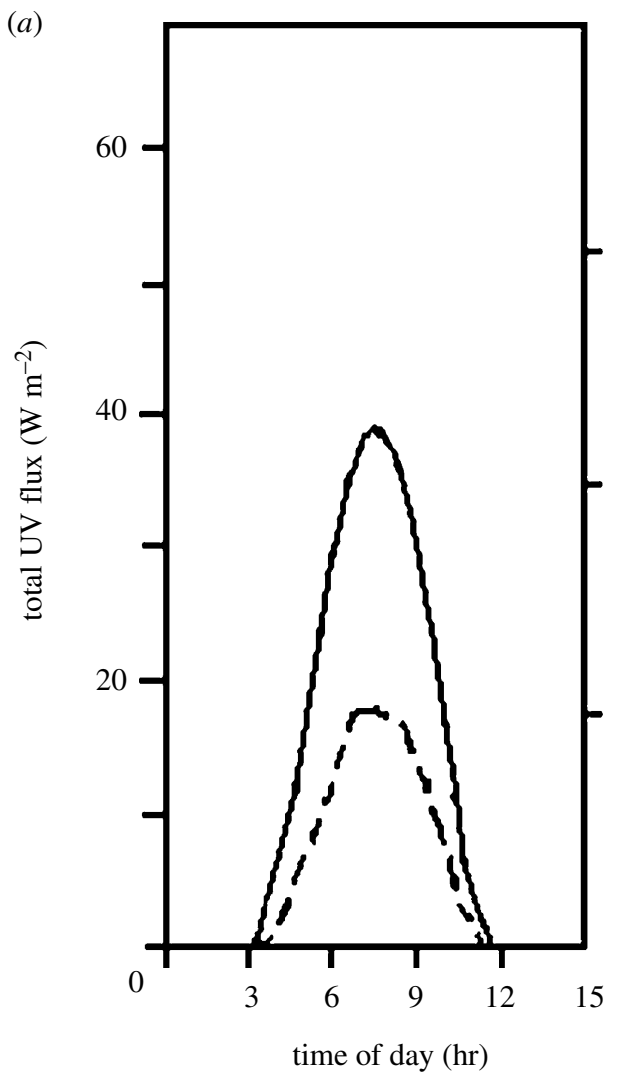

early Earth (b)

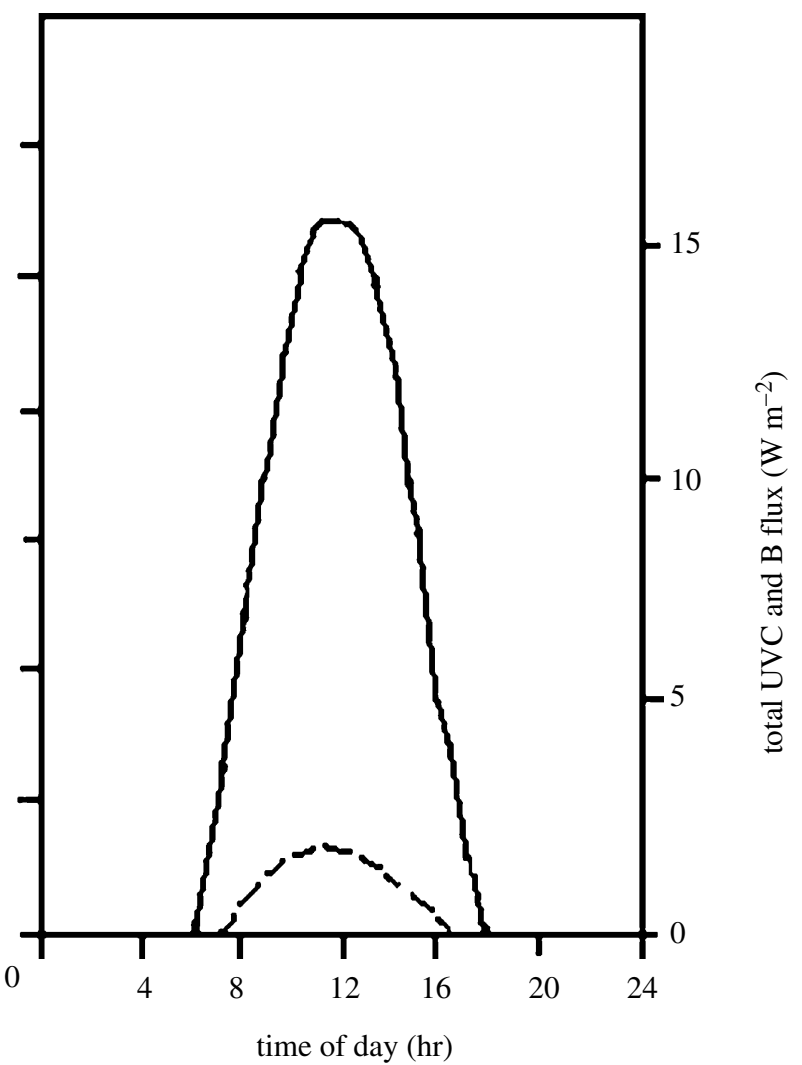

present day Earth

total UV flux

Figure 1. (a) UV flux at the surface of early Earth $(3.5 \mathrm{Ga})$ for the equator at vernal equinox. (b) UV flux on present-day Earth for the equator at vernal equinox. In both the cases, total UV flux is shown along with the total of UVC and UVB (the biologically most important wavelengths). In all the cases, optical depth of dust is taken as 0.1 . Here, UVB radiation is defined as $280-315 \mathrm{~nm}$ according to the conventions adopted by the International Commission on Illumination. (From Cockell et al. 2000).

$3.5 \mathrm{Ga}$ ago; Walker et al. 1983) would have also diminished the daily flux of radiation. At this timeperiod, the rotational obliquity of the Earth was already stabilized by the presence of the Moon.

The exact composition of the early Earth's atmosphere at $c a 3.5 \mathrm{Ga}$ is unknown. Empirical evidence from the rock record suggests that $\mathrm{CO}_{2}$ was a major component (Mel'nik 1982; Rye et al. 1995). However, given the lower luminosity of the Sun, either the concentrations of $\mathrm{CO}_{2}$ in the early atmosphere had to be extremely high (Walker et al. 1983) or one or more other greenhouse gases would be necessary to keep the early Earth from freezing over (Kasting \& Brown 1998). $\mathrm{CO}_{2}$ partial pressures of ca 1 bar were modelled by Kasting (1993) for the $3.5 \mathrm{Ga}$ Earth, while based on a geochemical analysis of the alteration rind of $3.2 \mathrm{Ga}$ Moodies Group (Barberton greenstone belt) pebbles, Hessler et al. (2004) hypothesize $\mathrm{CO}_{2}$ levels in the early atmosphere that were several orders of magnitude higher than those proposed by Rye et al. (1995) for the Earth at $2.7 \mathrm{Ga}$.

$\mathrm{CO}_{2}$, itself, is an effective absorber of UV radiation below $200 \mathrm{~nm}$, thus although the flux of higher energy radiation to the early Earth was higher, it would have been attenuated by the $\mathrm{CO}_{2}$ atmosphere. $\mathrm{CH}_{4}$ has been suggested as a greenhouse gas that could have contributed to the warming of the early atmosphere (Catling et al. 2001; Pavlov et al. 2001). Furthermore, photolysis of $\mathrm{CH}_{4}$ in the atmosphere produces an organic smog (Sagan \& Chyba 1997; Pavlov et al. 2001) that would also have absorbed UV radiation. Other gases in the atmosphere, such as volcanically outgassed $\mathrm{SO}_{2}$ (Córdoba-Jabonero et al. 2003), contributed to UV absorption. The early atmosphere most likely contained a certain amount of $\mathrm{N}_{2}$, but as this gas is not an absorber of UV radiation, its presence would have no effect on UV flux to the surface of the early Earth (Cockell et al. 2000). $\mathrm{H}_{2} \mathrm{O}$ vapour, on the other hand, does absorb UV radiation in wavelengths up to $350 \mathrm{~nm}$ (and in the process $\mathrm{H}_{2} \mathrm{O}_{2}$ is produced; Cockell et al. 2000). However, since $\mathrm{H}_{2} \mathrm{O}$ occurs in the troposphere and was overlain by $\mathrm{CO}_{2}$ at higher altitudes, attenuation of $\mathrm{UV}$ radiation by $\mathrm{H}_{2} \mathrm{O}$ absorption was probably minimal.

A final atmospheric component that could have influenced UV flux was dust. Since both volcanic activity and flux of bolides were higher on the early Earth, particulate matter in the atmosphere would have been generally higher than at present, thus resulting in a certain amount of scattering of UV radiation.

\section{(b) Life on the early Earth}

The vast majority of traces of life in the most ancient, well-preserved sediments on Earth, i.e. those of the 3.5-3.3 Ga Early to Mid-Archaean greenstone belts in the Pilbara, Northwest Australia and in Barberton, 
East South Africa, occur in shallow water sediments. Although there is a significant debate as to the biogenicity of a number of documented biosignatures, Westall \& Southam (2006) concluded, after reviewing all the data and assessing the reliability of the interpretations for biogenicity, that there is a significant body of bona fide evidence for the presence of abundant anaerobic life forms on the surface of the Earth in this period. Note that although life was widely distributed and had apparently invaded all the available habitats that have been preserved in the rock record, its physical expression was subtle and generally microscopic. This is in contrast to the striking, metre-high stromatolites that were typical of the Proterozoic era (Awramik \& Sprinkle 1999). However, macroscopically visible structures, such as small stromatolites, have nevertheless been described in the Early Mid-Archaean terrains (Lowe 1980; Walter et al. 1980; Byerly et al. 1986; Westall 2004; Allwood et al. in press).

The existence of traces of life in shallow water sedimentary environments in the Early MidArchaean begs the question of the influence of UV radiation at the surface of the Earth. The damage occasioned by predominantly UVB and UVC radiation affects the DNA of organisms most strongly (Rontó et al. 2003). Thus, in modern environments, organisms exposed to UV radiation require either efficient repair strategies to combat the damage and/ or survival strategies to escape UV radiation. The physical survival strategies include protection by a layer of sediment, dust, evaporite minerals or snow, or habitats within a rock (endolithic/chasmolithic; Cockell \& Raven 2004). Furthermore, in modern exposed environments, the outer layers of a microbial mat may consist of dead organisms that provide protection for those living in the deeper layers (Garcia-Pichel et al. 1994; Guerrero et al. 2002). Obviously, there is a trade-off between the depth to which the organisms need to be covered in order to be protected and the depth to which light can effectively penetrate the outer coat.

In the Early Mid-Archaean, microbial colonies inhabiting pore spaces within water-logged sediments (Westall et al. 2004, 2006) or in endolithic habitats, such as corrosion pits in the vitreous outer layers of pillow lavas (Furnes et al. 2004) would be protected from deleterious UV radiation, as suggested by Cockell et al. (2000). Nevertheless, there are numerous documents of microbial mats/stromatolites formed in the photic zone at the surface of Early Mid-Archaean shallow water sediments (Lowe 1980; Walter et al. 1980; Byerly et al. 1986; Walsh 1992, 2004; Hofmann et al. 1999; Westall 2004; Westall et al. 2001, 2002, 2004, 2006; Tice \& Lowe 2004; Allwood et al. in press). (NB, Lowe (1994) questioned the biogenicity of the Early Archaean stromatolites, but Allwood et al. (in press) and Westall \& Southam (2006) noted that these stromatolites contain both probable biogenic and abiogenic component). If the DNA-weighted UV radiation flux in the Early Archaean period was three orders of magnitude greater than at present, how could these early microbial mats have survived?

\section{(c) The Josefsdal Chert microbial mat}

\section{(3.5-3.3 Ga)}

In this paper, we document the existence of an Early Mid-Archaean filamentous microbial mat that formed on the surface of 3.5-3.3 Ga-old beach sediments in the Barberton greenstone belt. The exact stratigraphic assignation of the Josefsdal Chert is currently uncertain. It occurs in a fault-bounded volcano-sedimentary sliver that was attributed to the Hooggenoeg formation (3.472 $\pm 5-3.445 \pm 5 \mathrm{Ga}$, Armstrong et al. 1990) by Paris (1985), whereas Lowe \& Byerly (1999) attribute it to the Kromberg Formation (3.445 $\pm 5-3.334 \pm$ 3 Ga, Byerly et al. 1996).

The degree of preservation exhibited by the mat has permitted a multidisciplinary investigation that was able to establish the biogenicity of this structure with an extremely high degree of probability. Considering the recent debate concerning the interpretation of certain filamentous carbonaceous structures in similarly aged rocks from the Pilbara as oxygenic photosynthesizing cyanobacteria (Buick 1990; Schopf 1993; Brasier et al. 2002), this study contributes significantly to the understanding of the differences between abiogenic artefacts and highly probable microfossils. The combination of petrographic and high-resolution scanning electron microscope (SEM) observation with electron diffusion X-ray spectrometry (EDX), microprobe, Raman spectroscopy and carbon isotope analyses, is therefore a powerful tool for obtaining detailed information regarding not only the nature of the biofilms, but also their interaction with the environment of formation on a micrometre scale (cf. Westall 2005), as well as permitting better understanding of the mode of preservation of the early micro-organisms.

This is the earliest documented example of life in a subaerial habitat. The mat, most likely formed by anoxygenic photosynthetic micro-organisms, was directly exposed to the atmosphere, as testified by embedded layers of evaporite minerals and desiccation cracks in its surface, and therefore to UV radiation. In this case, absorption of UV radiation by water cannot be invoked as protection for the micro-organisms. The existence of such an exposed mat has therefore important implications for the conditions of survival of micro-organisms at the surface of the early Earth, as well as for the early atmosphere and its influence on the flux of UV radiation to the surface.

\section{MATERIAL AND METHODS}

\section{(a) Sample}

We have used this combination of techniques on a sample from a chert horizon in the Onverwacht Group located in the upper part of the Josefsdal Valley $\left(25^{\circ} 57.949^{\prime} \mathrm{S}\right.$; $\left.31^{\circ} 04.712^{\prime} \mathrm{E}\right)$, near the asbestos mining village of Msauli in the Barberton Greenstone Belt (figure 2). The chert horizon is here named the Josefdal Chert. It consists of two chert layers separated by silicified pillow basalt. Our sample (96SA05) was obtained from the upper layer (also stratigraphically). A second sample (99SA07) from the same outcrop was used for additional carbon isotope analyses. The black and white/green banded cherts consist of silicified volcaniclastic sediments that exhibit a variety of sedimentary structures indicative of deposition in a shallow water environment, such as channel fill, ripple, flaser- and graded 


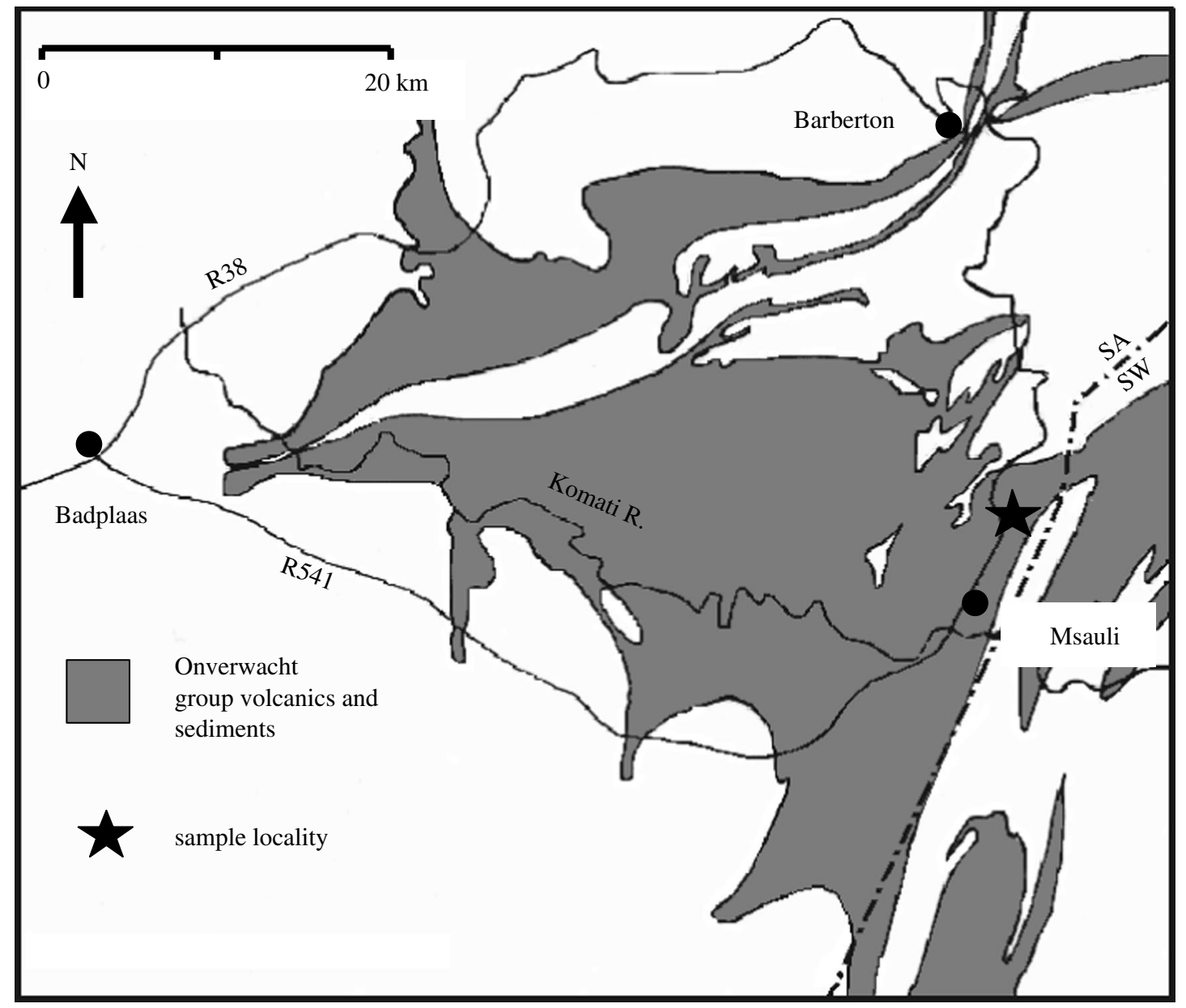

Figure 2. Location map of the Josefsdal Chert in the Barberton greenstone belt (simplified after Lowe \& Byerly 1999).

bedding, and synsedimentary deformation. The rocks have been subjected to low-grade metamorphism (lowermost greenschist facies).

\section{(b) Microprobe and EDX analyses}

Microprobe and EDX analyses of the chert sample were made with a Cameca SX50 Microprobe at the BRGM, Orléans, for major, minor and trace element analyses of individual protoparticles (e.g. spherulites and volcanic shards) and other minerals (e.g. barite, Ti-oxide and $\mathrm{Fe}$-oxides) in polished thin section. The working conditions were: acceleration voltage $15 \mathrm{kV}$, beam current $12 \mathrm{nA}$ and beam width $1 \mu \mathrm{m}^{2}$. The standards used included: $\mathrm{K}$, orthoclase $\left(\mathrm{KAlSi}_{3} \mathrm{O}_{8}\right) ; \mathrm{Ti}, \mathrm{MnTiO} 3$ (synthetic); $\mathrm{Fe}$, hematite $\left(\mathrm{Fe}_{2} \mathrm{O}_{3}\right) ; \mathrm{Na}$, albite $\left(\mathrm{NaAlSi}_{3} \mathrm{O}_{8}\right) ; \mathrm{Ca}$, andradite $\left(\mathrm{Ca}_{3} \mathrm{Fe}_{2} \mathrm{Si}_{3} \mathrm{O}_{12}\right) ; \mathrm{Cl}$, vanadinite $\left(\mathrm{Pb}_{5}\left(\mathrm{VO}_{4}\right)_{3} \mathrm{Cl}\right) ; \mathrm{Cu}, \mathrm{Cu}$ metal; $\mathrm{Si}$, albite $\left(\mathrm{NaAlSi}_{3} \mathrm{O}_{8}\right) ; \mathrm{S}$, barytes $\left(\mathrm{BaSO}_{4}\right) ; \mathrm{U}, \mathrm{UO}_{2}$; $\mathrm{Cr}, \mathrm{Cr}_{2} \mathrm{O}_{3}$ (synthetic); $\mathrm{Al}$, corundum $\left(\mathrm{Al}_{2} \mathrm{O}_{3}\right) ; \mathrm{V}$, vanadinite $\left(\mathrm{Pb}_{5}\left(\mathrm{VO}_{4}\right)_{3} \mathrm{Cl}\right)$ and $\mathrm{Mg}$, olivine $(\mathrm{Mg}, \mathrm{Fe})_{2} \mathrm{SiO}_{4}$. Spot sizes ranged from 1 to $12 \mu \mathrm{m}^{2}$ areas.

Spot analyses (approx. $1 \mu \mathrm{m}$ ) of exactly the same protoparticles were made by EDX with the Hitachi S4200 field emission gun SEM (FEG-SEM). These analyses are semi-quantitative.

\section{(c) Optical and scanning electron microscope preparation and observations}

Thin section observations of structure and mineralogy were made in transmitted and reflected light with an Olympus BX51optical microscope, fitted with an Olympus TH4-200 reflected light source. SEM observations were made on: (i) non-etched and etched freshly broken surfaces and (ii) non-etched and etched polished thin section surfaces. The samples were thoroughly cleaned before being etched in the fumes of $48 \% \mathrm{HF}$ for $15 \mathrm{~min}$ to $1 \mathrm{~h}$. After etching, the samples were thoroughly rinsed in milli-Q water to eliminate all the traces of $\mathrm{HF}$. The samples were coated with $\mathrm{Au}, \mathrm{Au} / \mathrm{Pt}$ or $\mathrm{C}$ (for the polished thin section). The observations were made over a period of 8 years on different SEMs including a Philips 515 (University of Bologna) with EDX, a Philips FEG-SEM XL40 and a JEOL6340 (FEG-SEM; JSCHouston) and light element EDX detector and an Hitachi S4200 (FEG) with light element EDX detector at the University of Orléans.

The SEM investigations were made of sections across the mat cut with a focused ion beam (FIB) using an FEI StrataTM 235 instrument (University of Modena). The observations were made in secondary, backscatter and ion beam mode with the same instrument and with the Hitachi S4200 (FEG) at the University of Orléans (EDX analyses were made on the FIB-cut sections of the mat were also made with the latter instrument).

\section{(d) Bulk organic carbon and $\delta^{13} C$ analyses}

Preliminary bulk organic carbon and $\delta^{13} \mathrm{C}$ analyses were made on the same sample of black chert in which the mat-like structure was observed (96SA05; cf. Westall et al. 2001) as well as on a second sample of black chert from the same exposure (99SA07). In the first case, the subsample analysed had all surfaces cut-off using a diamond saw, the black chert layer then cut out of the centre of the remaining piece of sample. During laboratory handling, all contacts with plastics 

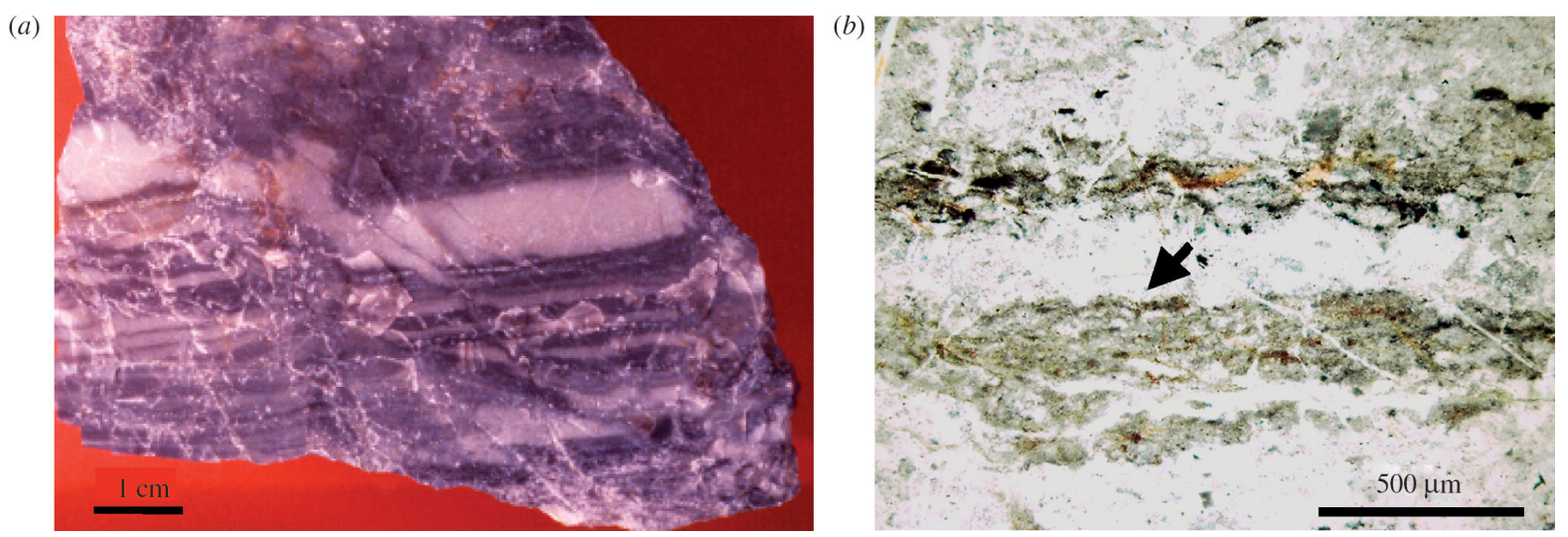

Figure 3. (a) Photograph of the Josefsdal Chert sample 96SA05 showing the alternation of black and greenish-white layers. (b) Optical microscope image of one of the black layers at the top of a fining upwards sequence, illustrating its slightly laminated structure and its sharp upper contact with the overlying (coarser-grained) greenish-white layer (arrow). The lower boundary is gradational.

and other contaminating materials were scrupulously avoided. The sub-sample was first treated with acid, but showed no evidence for any carbonate carbon. For organic carbon determination, ca $100 \mathrm{mg}$ crushed, acid-treated sample was placed in a $6 \mathrm{~mm}$ OD quartz tube with $c a 0.8 \mathrm{~g}$ on $\mathrm{CuO}$, small amounts of $\mathrm{Cu}$ turnings, and $\mathrm{Ag}$ wire. All the ingredients had been previously cleaned by firing $\left(\mathrm{CuO}\right.$ in $\mathrm{O}_{2}$ at $900^{\circ} \mathrm{C} ; \mathrm{Au}, \mathrm{Cu}$ in $\mathrm{H}_{2}$ at $400^{\circ} \mathrm{C}$ ). The sample tube was evacuated, sealed with a torch, then combusted in a furnace at $900^{\circ} \mathrm{C}$ for $1 \mathrm{~h}$ followed by overnight cooling. The $\mathrm{CO}_{2}$ produced was extracted from the tube into a vacuum system, dried using a dry ice-cooled trap, measured in a constant volume manometer and transferred to a nuclide analysis associates 6-60 mass spectrometer for stable carbon isotope determination. Appropriate corrections were made and the isotope results expressed in parts per thousand (\%o) relative to the international V-PDB scale as $\delta^{13} \mathrm{C}$ with an estimated standard error of $\pm 0.1 \%$.

The second subsample (99SA07) was analysed according to the methods of Matthews \& Hayes (1978) with a VG/ Fisons/Micromass 'Isochrom-EA' system, consisting of an elemental analyser (EA1500 Series 2) on line to an Optima mass spectrometer operating in $\mathrm{He}$ continuous flow mode (Grassineau in press). The whole rock sample was first treated in $20 \% \mathrm{HCl}$ at $120^{\circ} \mathrm{C}$ for $12 \mathrm{~h}$. Hand-picked chips of the whole rock sample were first cleaned with methanol solvent in an ultrasonic bath to remove any modern contamination. They were then treated in $20 \% \mathrm{HCl}$ at $120^{\circ} \mathrm{C}$ for $12 \mathrm{~h}$ to remove possible carbonate and finally rinsed in distilled water. The chips (greater than $500 \mu \mathrm{m}$ ) were measured with a quantity of $30 \mathrm{mg}$ (weight for samples under $0.1 \mathrm{wt} \% \mathrm{C}$ ) and a precision of $\pm 0.1 \%$. The standards analysed, including NBS-21 and IAEA-CO9, cover a range of values from -47.1 to $+3.3 \%$, with a precision better than \pm $0.1 \%$. The standard calibration obtained is used to correct the raw sample data in order to obtain the final corrected results that are expressed in parts per thousand and the V-PDB scale. The C concentrations were calculated by deducting the blank contamination values obtained from measurements of tin capsules (less than 34 p.p.m. C).

Raman spectral analysis of both the carbon in the FIB-cut sections of the mat as well as in the dense brown parts of the dark layers in a thin section were made with a Jobin-Yvon model T64000 instrument using an Olympus BX40 microscope. The analyses were made in the green wavelength $(514 \mathrm{~nm})$ with a simple monochromator and a notch filter. The laser power was $1 \mathrm{~mW}$.

\section{(e) Criteria for microfossil identification}

We followed the criteria outlined in detail in Westall et al. (2006) that can be summarized as follows:

Before a potentially biogenic object in a rock can be identified as such, three conditions must be fulfilled: (i) the rock must have been formed in an environment compatible with the existence of micro-organisms; (ii) the object(s) must demonstrate evidence for originality or syngenicity with the rock formation and (iii) the objects(s) must show evidence of biogenicity. The combination of these observations is then evaluated to arrive at an estimation of the probability of biogenicity.

The biogenicity criteria we use include phenomena that are related to the structural aspects of a cell (i.e. the morphology of a cell, its colony and its biofilm or mat) and to its living processes (i.e. the chemical composition of its constituent parts, the fractionation of various elements, such as $\mathrm{C}, \mathrm{S}, \mathrm{Fe}$ ). They include (i) the morphological aspects of individual micro-organisms (size, shape, cell division, cell envelope texture, evidence for lysis, i.e. cell death and flexibility); (ii) colonial and biofilm characteristics (association with a number of other organisms of the same species, association with different species in the vicinity (consortium), association with microbially produced polymer (extracellular polymeric substances, EPS), and formation of biofilms and (iii) chemical and isotopic composition (NB, microfossils do not always contain carbon, e.g. in oxidizing hot spring sinters, micro-organisms are coated with silica but no trace of C remains; Cady \& Farmer 1996).

Two other, related considerations of fundamental importance to the study of fossil bacteria are: (i) the interactions between individual micro-organisms and their biofilms with their microenvironment and (ii) the fact that even extremely ephemeral microbial 'blooms' have the potential of being preserved.

\section{RESULTS}

\section{(a) Sedimentology and geochemistry}

Optical microscope observation of the sample shows that it consists of millimetre to centimetre thick layers of black and white or pale green chert (figure $3 a$ ). The difference in colour is related both to grain size, sorting and composition, with the paler layers forming the base of a grading upwards sequence and the black layers forming the top of this sequence. In thin section, the 


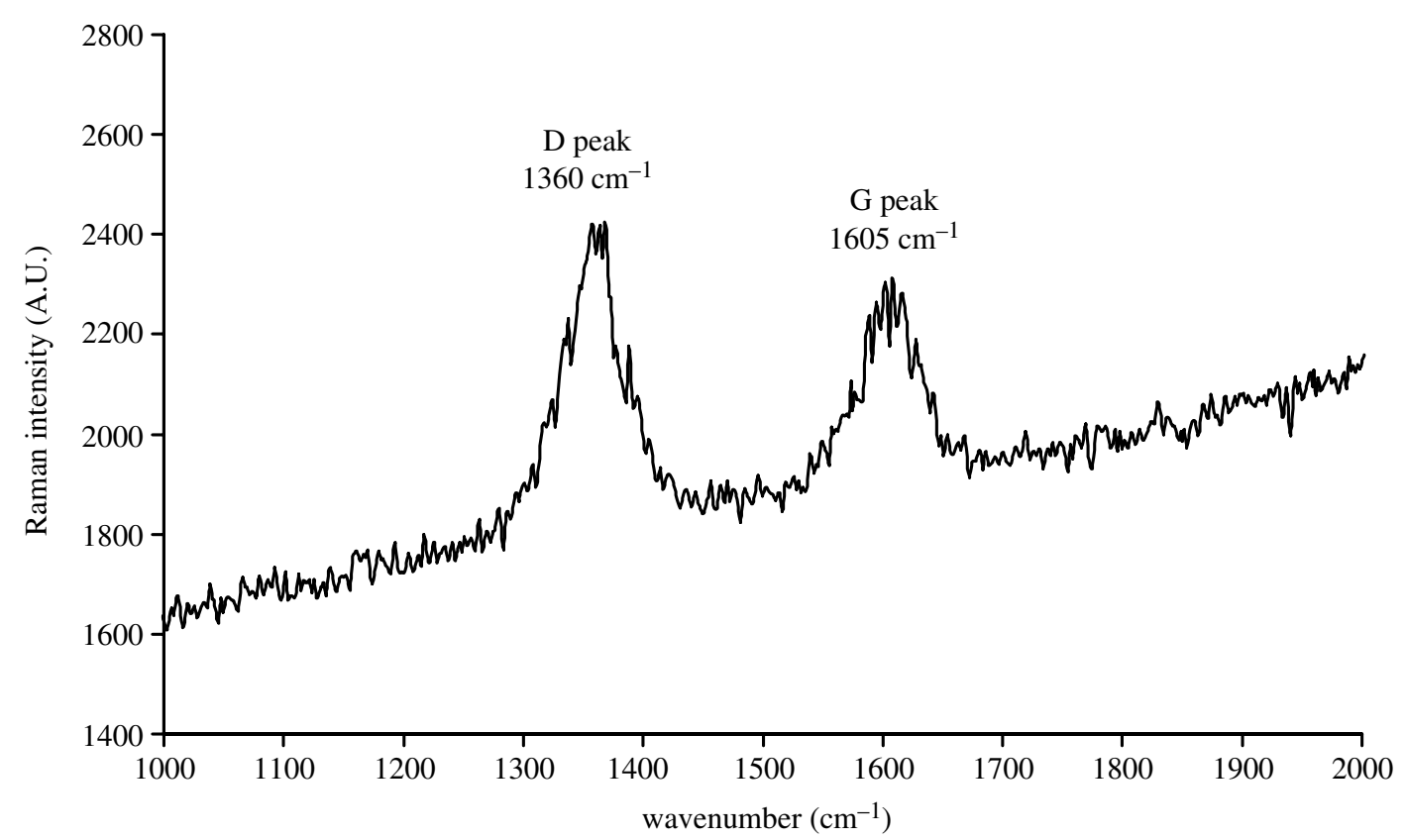

Figure 4. Raman spectral signature obtained from the exposed FIB-cut section across the mat-like structure documenting the kerogenous composition of the interior of the mat. The presence of a well-defined D and $\mathrm{G}$ peak demonstrates that the kerogen is mature and is not a recent phenomenon.

black layers are thin and undulating (tens to ca $200 \mu \mathrm{m}$ ) and consist themselves of packets of thinner, less than $10 \mu \mathrm{m}$ thick concentrations of mostly minute pseudomorphed pyrite crystals (a few micrometres in size) and even smaller Ti-oxide spherules $(1-2 \mu \mathrm{m})$ in a diffuse, brownish matrix (figure $3 b$ ). The pyrite crystals have been replaced by Fe-oxide (goethite), but EDX and microprobe measurements on individual crystals still document $\mathrm{S}$ and occasionally a C-rich oval core. Although generally discontinuous, frequently the topmost layer of the black packet of layers is continuous (figure $3 b$ ), indicating a short cessation of sedimentation and the temporary stabilization of the sediment surface.

Very early diagenetic alteration of the volcanic clasts resulted in their initial conversion to the phyllosilicate fuchsite (Cr-rich muscovite). Subsequent early silicification replaced the outer parts of the clasts by microcrystalline quartz and cemented the sediment. Ti-oxide crystals, $1-2 \mu \mathrm{m}$ in size, coat the volcanic clasts in the light layers, whereas in the black layers they are coated by both Ti-oxide and $\mathrm{FeS}$ crystallites. Barite crystals containing trace amounts of $\mathrm{Co}$ and $\mathrm{C}$ also occur in the black layers (bulk measurement of selected pieces of the black layers gave an $S$ concentration of 160 p.p.m.).

\section{(b) Bulk carbon and carbon isotopes}

The subsample of sample 96SA05 analysed for carbon isotopes had a reduced carbon content of $0.01 \mathrm{wt} \%$ and a $\delta^{13} \mathrm{C}$ value of $-22.7 \pm 0.1 \%$. The black layer in sample 99SA07 had a slightly higher reduced carbon content of $0.07 \mathrm{wt} \%$ and a $\delta^{13} \mathrm{C}$ value of $-26.8 \pm$ $0.1 \%$. Raman spectroscopy revealed that the carbonaceous mat consists of mature kerogen (figure 4).

\section{(c) Microbial mat-like structure}

A $1-4 \mu \mathrm{m}$ thick mat-like structure, distributed irregularly over a surface area of $6 \mathrm{~mm}^{2}$ on the top of one of these black layers (figure 5), is exposed on a freshly broken surface, as the microscopy shows, which is a bedding plane and not a previously formed fracture surface (see also a preliminary description in Westall et al. 2001; figure $9 a, b$ ). We thus have a planar view of the microbial mat-like structure and consequently know its orientation, a factor that is fundamental for investigating mat construction and interaction with the underlying substrate, since different layers of the matlike structure are visible in lateral extension. Moreover, FIB-cut sections across the mat have provided valuable information concerning the complex vertical architecture of the mat, its internal structure, mode of fossilization and the state of the kerogen within it. Figure 10 shows that the mat is coated with a thin layer of silica, a few tens of nanometres in thickness that faithfully preserves its external morphology. Within the mat, however, all trace of its filamentous habit has disappeared and the organic matter has degraded into an amorphous to alveolar-like structured kerogen that has been partially mineralized.

The mat-like structure was formed by multiple layers of parallel filaments (figure $6 b, c$ ) that have a consistent diameter of $0.25 \mu \mathrm{m}$ along their lengths (figures $6 f$ and $8 b, c$ ) and that are thickly coated with a heterogeneously textured film that ranges from ropy, granular, smooth to holey (figures $6 b, c, 8 a$ and $9 d$ ). The main part of this structure is laterally continuous with a thin (less than $1 \mu \mathrm{m}$ or more) film containing small patches of filamentous mat-like structure (less than tens of $\mu \mathrm{m}^{2}$ or more), whose filaments have the same orientation as those in the main mat. The total lengths of the filaments are unknown because they are interwoven with each other and thickly coated by the film. However, they are probably of the order of several tens of micrometres in length although visible portions of individual filaments only reach up to $5 \mu \mathrm{m}$ in length (figures $6 f$ and $8 b, c$ ). The filaments are commonly 


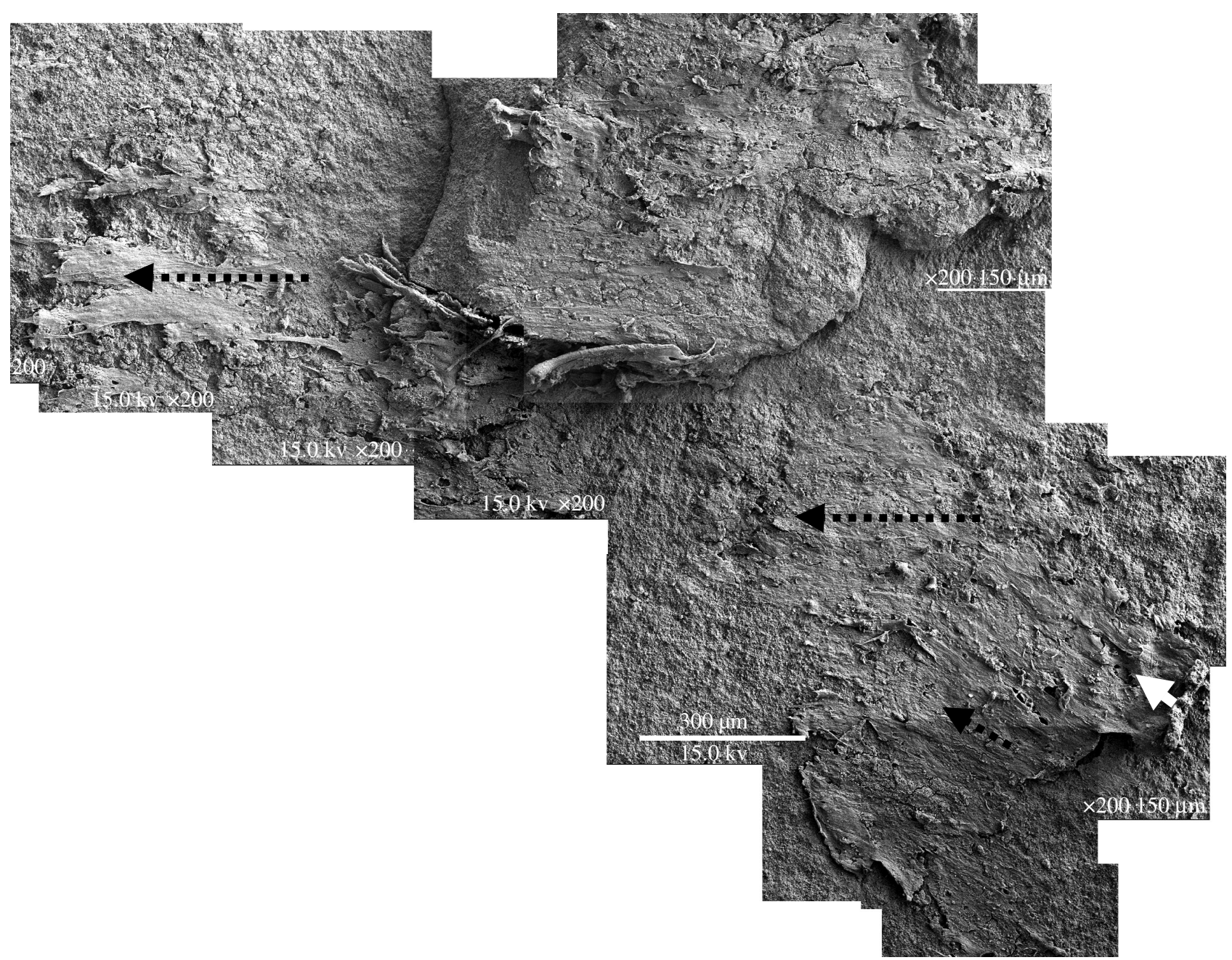

Figure 5. SEM micrograph composite of half of the microbial mat that was exposed across the freshly broken surface, showing it in plan view. The large black arrows mark the main direction of current flow. The smaller dotted black arrow marks a $35-40^{\circ}$ change in flow direction in the uppermost mat layer. The small white arrow indicates the direction of overturning of a portion of mat that has curled over under the influence of the current flow.

interwoven with each other, producing thicker fibrous structures up to several micrometres in diameter. Flexibility of the filaments is demonstrated by overturning (figures $6 a$ and $9 c$ ) and their curling around embedded volcanic particles and authigenic minerals (figure $7 a, d)$. (NB, the direction of overturning is the same as that of the filament orientation.) Other areas of the mat-like structure have a torn appearance where portions of the film have been removed (figure $8 a$ ). The uppermost layer of the mats has a slightly different orientation to the main part of the mat (by ca 35-40 not illustrated). Combined, these observations indicate that the mat-like structure was most likely formed under the influence of flowing water.

A small group of rod and vibroid-shaped structures embedded in a smooth film (figure $6 e$; see also preliminary description in Westall et al. 2001, fig. 4a,b) was observed in a region of the sample, where the main mat-like structure had peeled away to reveal the underlying, thin, granular crust (mineralized kerogen). These ca $1 \mu \mathrm{m}$ diameter and 2-3.8 $\mu \mathrm{m}$ long structures are sometimes attached to each other at their apices, suggesting binary fission.

The film has trapped and embedded detrital particles (e.g. spherulites, volcanic clasts and quartz grains). Minute acicular minerals have precipitated within the degraded kerogen (figure 11b) and larger mostly euhedral crystals are embedded in the upper part of the mat (figures 6 and $11 c, d$ ), demonstrating authigenic growth at the same time as the formation of the mat-like structure. For example, figure $11 d$ shows an angular quartz grain 'floating' within the heterogeneous mélange of authigenic minerals and kerogen that characterized the body of the mat in this area. The

Figure 6. (Overleaf.) SEM micrographs documenting different characteristics of the microbial mat. (a) Parallel and overturned filaments (white arrow) indicating flow direction (large black arrow). Note the blocky minerals $(M)$ embedded in the mat. (b) Desiccation cracks (arrow) in the film are common. (c) Intercalated evaporite-encrusted mat (em) beneath smooth to ropy surfaced mat (srm) that 'flows' around an evaporite precipitate (arrow). (d) Evaporite minerals include oval to platy pseudogypsum (see also the desert-rose twinning in the inset) and acicular pseudo-aragonite. A strand of filamentous film partially covers some acicular crystals (arrow). (e) Small association of rare rod/vibroid-shaped structures embedded in smooth EPS. Some individuals are attached to each other at their apices (black arrow). $(f)$ Rare, isolated portion of a turgid filament (arrow). The filaments are usually deeply embedded in the polymer film (compare with figure $8 b$ ). 

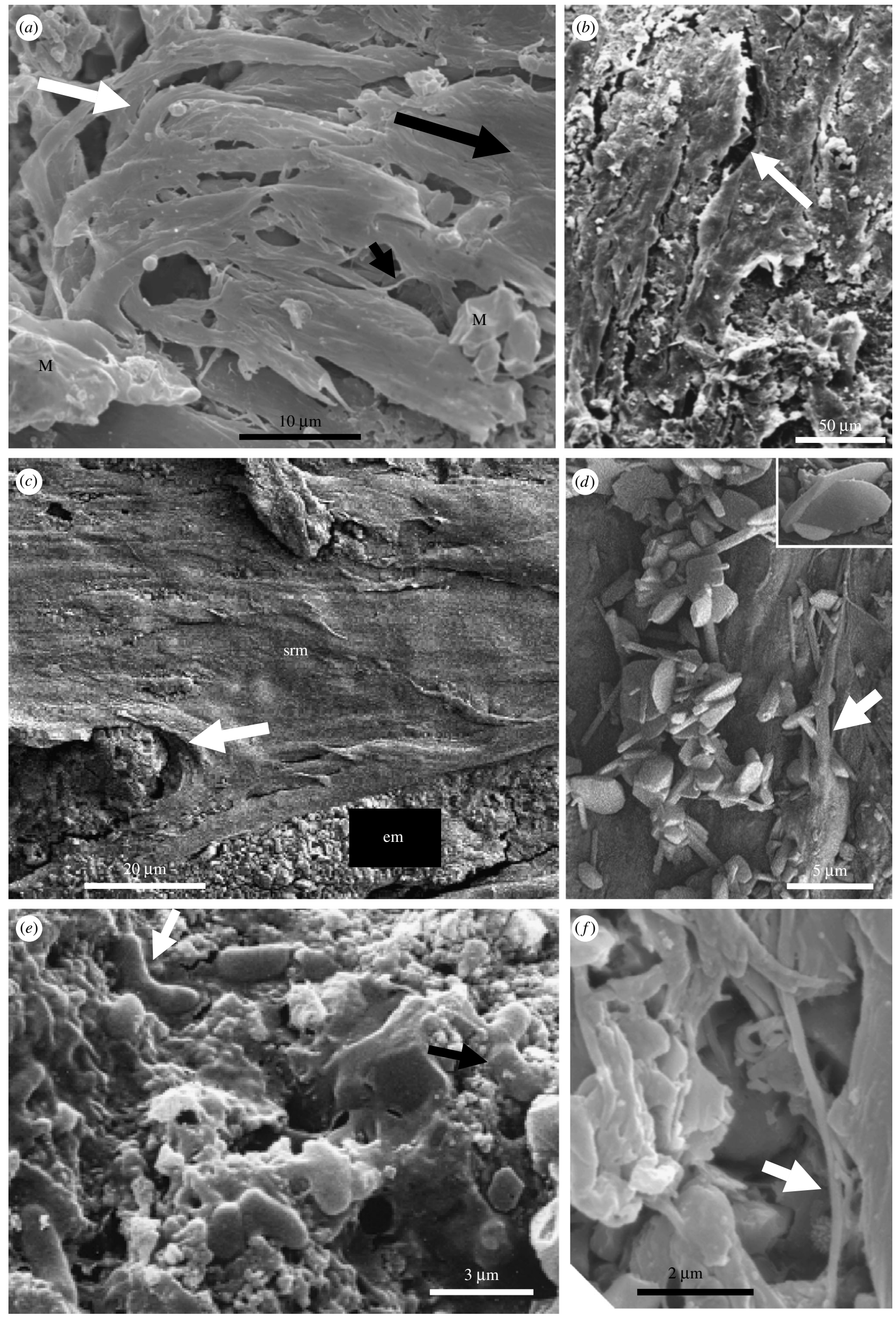

Figure 6. (Caption Overleaf.) 

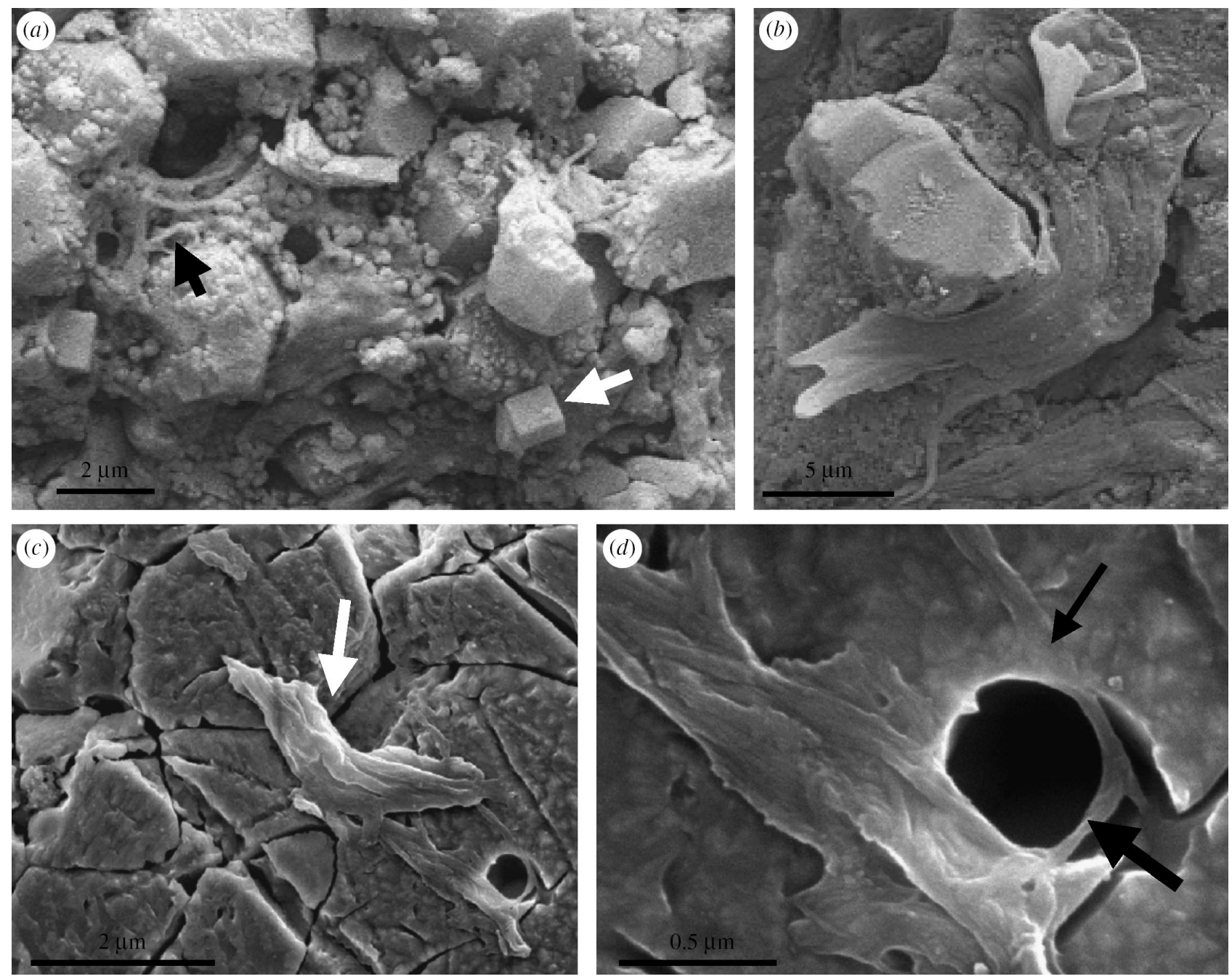

Figure 7. (a) The main mat has peeled away from this area to reveal the initial intimate intergrowth of the filaments (black arrow) and granular precipitates (including a halide, white arrow) with the underlying sediment particles. (b) Portion of the filamentous mat 'flowing' around a trapped detrital particle. $(c$ and $d$ ) Filaments in a lightly etched (15 min), polished thin section surface. The filaments traverse the boundary between two quartz crystals (arrow in $c$ ) and are clearly embedded in the quartz (small arrow in $d$ ), showing that they predate the formation of the quartz matrix. The filaments were bent around a particle (represented by an empty mould; large arrow), demonstrating flexibility $(d)$.

authigenic minerals embedded in the mat surface have morphologies and compositions that are indicative of an evaporite suite of minerals that includes aragonite (figure $6 d$ ), high $\mathrm{Mg}$ calcite (figure $8 b$ ) and possibly gypsum or anhydrite (figures $6 d$ and 11) as well as a halide (either sylvite; $\mathrm{KCl}$ or carrobite, $\mathrm{KF}$; figure $9 d$ ), the latter apparently deposited lastly, as is common in most evaporite precipitation sequences. All the anions of these minerals, however, have been replaced by fluorine. An evaporite interpretation is consistent with the inferred environment of deposition (shallow water/ littoral) and the cracked, desiccated appearance of the mat-like structure that indicates subaerial exposure (figures 5 and $6 b$ ). Moreover, filaments stretched across the cracks demonstrate plastic deformation of the mat and indicate that it was desiccated while in a still 'semi-plastic' state before silicification (figure $8 e$ ).

\section{DISCUSSION}

\section{(a) Local environment of deposition}

The macroscopic and microscopic sedimentological structures indicate sediment deposition in a shallow water to littoral environment. Within this global environment, the fine-scale fining-upwards sequences observed in thin section are suggestive of a tidal environment. The continuous tops of the black layers perhaps reflect a brief period of quiescence in deposition before the next influx of sediments. The filamentous matlike structure formed on top of one of the black layers and is immediately overlain by a greenish-white layer, implying formation during the short period of quiescence prior to the next major influx of sediment. Parallel streamlining in the same direction of all the portions of the filamentous mat, the overturning of parts of the mat and mechanical tearing of other parts, indicate that the mat must have formed under flowing water. The change of $c a 40^{\circ}$ in the direction of the filaments in the uppermost layers probably indicates a change in the orientation of flow of the water. Although formed under flowing water, the intergrowth of a suite of evaporite minerals (typical of those forming in evaporitic environments, e.g. Vai \& Ricci Lucchi 1977) within the surface of the mat, together with the cracking of the upper surface of the mat, demonstrate that it must have undergone subaerial exposure with desiccation in an evaporitic environment. It could be 

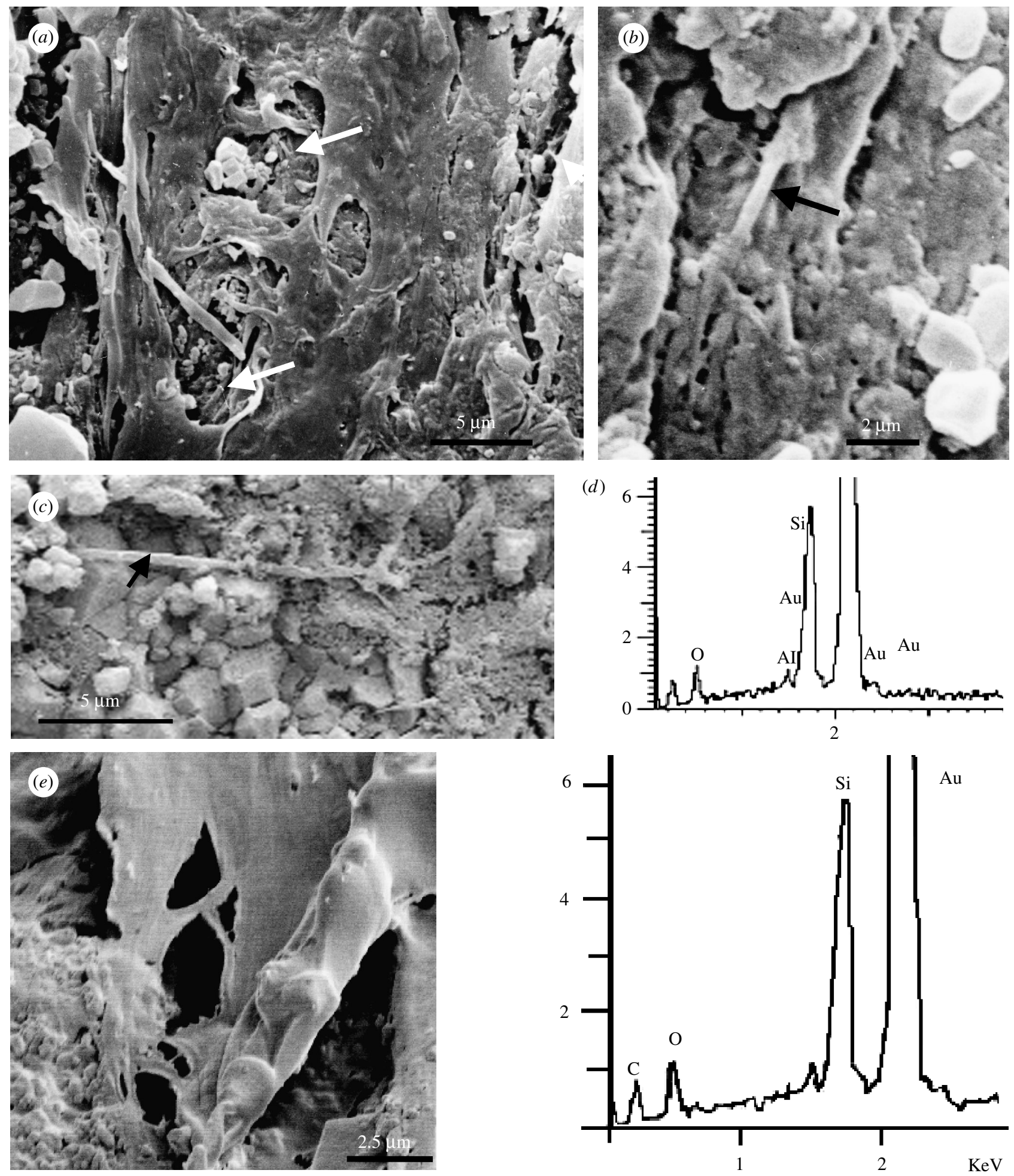

Figure 8. (a) Areas of the smooth to ropy-surfaced mat that have suffered from mechanical tearing (arrows). (b) Filament deeply embedded in EPS (arrow). Note the high-Mg calcite pseudomorphs embedded in the mat surface on the right. (c) Individual filament (arrow). (d) EDX spot measurement of the filament. Note the C peak in the spectrum (arrow). (e) Part of mat surface showing plastic deformation of the filaments and polymer across cracks indicating desiccation before silicification.

argued that the desiccation cracks may be related to dewatering processes accompanying the diagenetic crystallization of the silica that coated and impregnated the mat. However, the fact that cracks in the mat have filaments stretched across them, indicating plastic deformation, demonstrates that the desiccation occurred before silicification, otherwise the delicate, silicified filaments would have shown brittle fracture. Furthermore, to our knowledge, there are no known mechanisms for forming the suite of evaporite minerals described here in other than semi-subaerial to subaerial evaporitic environments. We therefore conclude that these observations point strongly to formation of the filamentous mat in an evaporitic littoral environment.

\section{(b) Biogenicity}

In summary, the combined morphological and chemical characteristics of the individual filaments 


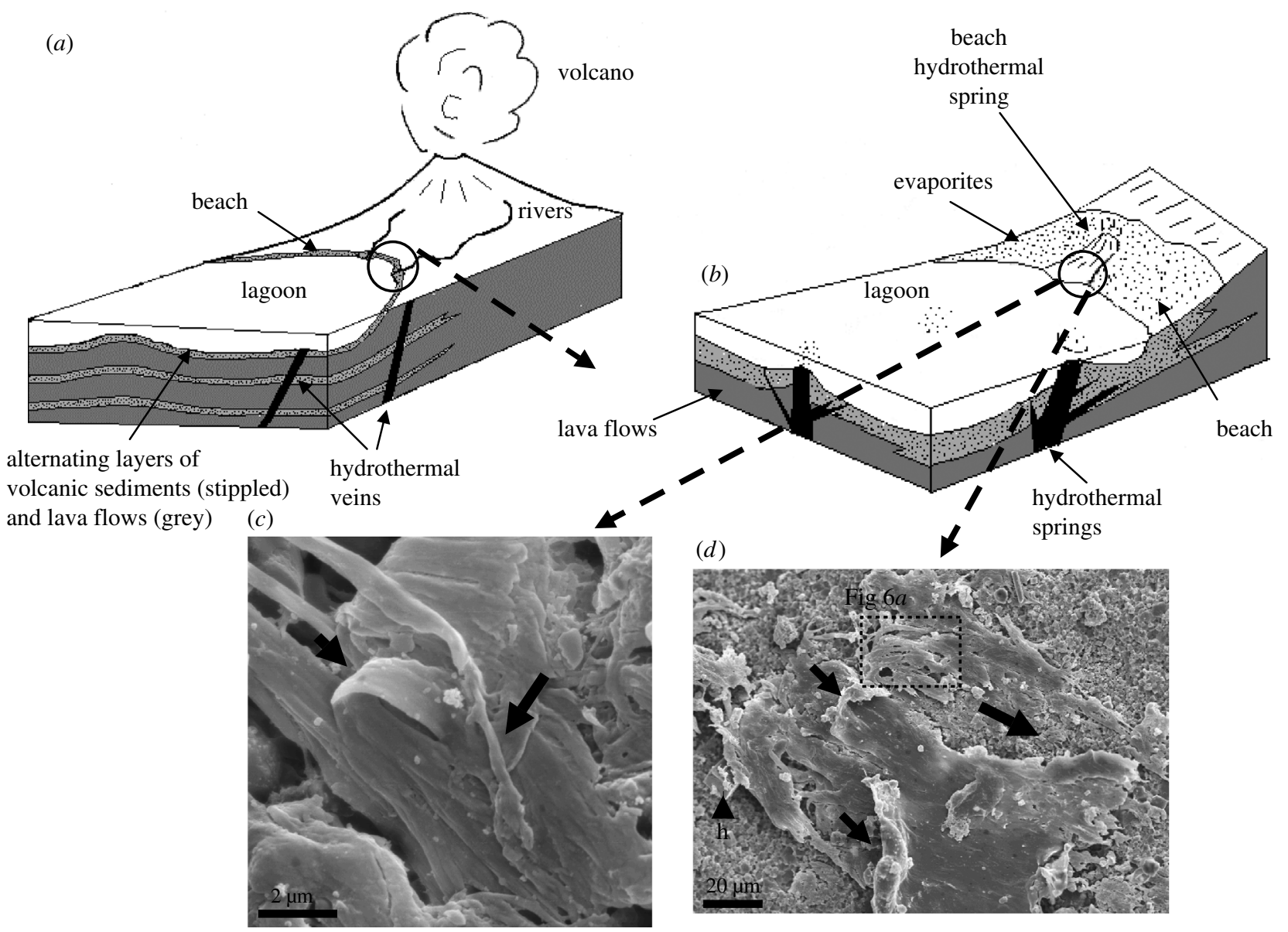

Figure 9. Hypothetical Early Mid-Archaean coastal landscape in the Josefsdal area. (a) Volcano erupting ashy material onto the coastal plain and into the lagoon; rivers transporting eroded sediments into the lagoon surrounded by a strip of beach sediments; alternating layers of lava flows separated by thin layers of sediments underling the lagoon and coastal plain; hydrothermal dykes or veins cut through the lava and sediment layers to reach the surface. (b) Close up view of the beach area showing the prevalence of hydrothermal springs, also on the beach, and evaporite deposits on the beach. ( $c$ and $d$ ) Close up views (SEM) of the surface of the sediments on the beach showing different aspects of the microbial biofilm formed in the vicinity of the spring. In (c) a portion of the filamentous mat is overturned (small arrow) and overlain by another strand of filamentous mat (large arrow). In $(d)$ the current direction is given by the main arrow and overturned portions of the film are marked by small arrows. The location of figure $6 a$ is shown. A large halide hopper (h) is wedged under the mat.

and $\mathrm{rod} /$ vibroid-shaped structures are identical to those known for modern prokaryotes. They exhibit other characteristics that are typical of modern microorganisms including colony, biofilm and mat formation, as well as direct interaction with their environment. We therefore conclude that these structures have a strong probability of representing biofilm-forming microbial filaments and rods/vibroids. We detail our arguments here.

(i) The morphological aspects of individual micro-organisms Size. The filaments are $0.25 \mu \mathrm{m}$ diameter and tens of micrometres in length size (figures $6 f, 7 d$ and $8 b, c ; \mathrm{NB}$, microbial filaments of a similar size have been observed in modern hot spring environments; Mountain et al. (2003) Handley et al. (2005) and Handley et al. (op.cit.) noted that the silicified filaments, as individuals, were not visible by optical microscopy in petrological thin section. This is not surprising since they are below the limit of resolution of an optical microscope owing to their very thin diameter). The faint filamentous texture that is observable in figure $3 b$ probably results from packets of filaments forming thicker bundles, as shown in figures 6, 10 and 11a).
The rod/vibroid-shaped structures are $1 \mu \mathrm{m}$ in diameter and between 2 and $3.8 \mu \mathrm{m}$ in length (figure 6e).

Shape. The filaments have a turgid filamentous shape that is consistent along their length (figures $6 f$, $7 d$ and $8 b, c)$. The rod/vibroid structures exhibit a turgid structure, are characterized by rounded crosssections and rounded terminations, and are shaped as straight or curved rods (figure $6 e$ ).

Cell division. A number of rod/vibroid-shaped individuals are attached to each other at their extremities as iffossilized during cell division (figure 6e).

Cell envelope texture. The surfaces of both the filaments (where visible: they are invariably coated by a thick film) and the rod/vibroid-shaped structures are smooth (figures $6 e, f, 7 d$ and $8 b$ ).

Evidence of lysis. Almost all the filamentous individuals and all of the rod/vibroid-shaped structures exhibit a turgid, non-lysed (or non-collapsed) structure (figures $6 e, f, 7 d$ and $8 b$ ), suggesting that they were probably still living when silicified.

Flexibility. Evidence of flexibility and plastic deformation is demonstrated by a number of individual filaments that are curled around obstacles, 
(a)

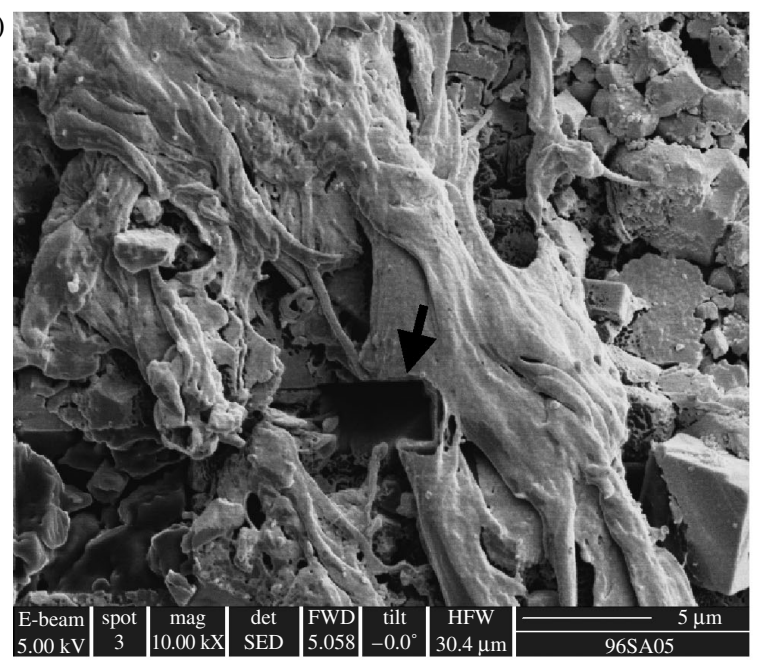

(b)

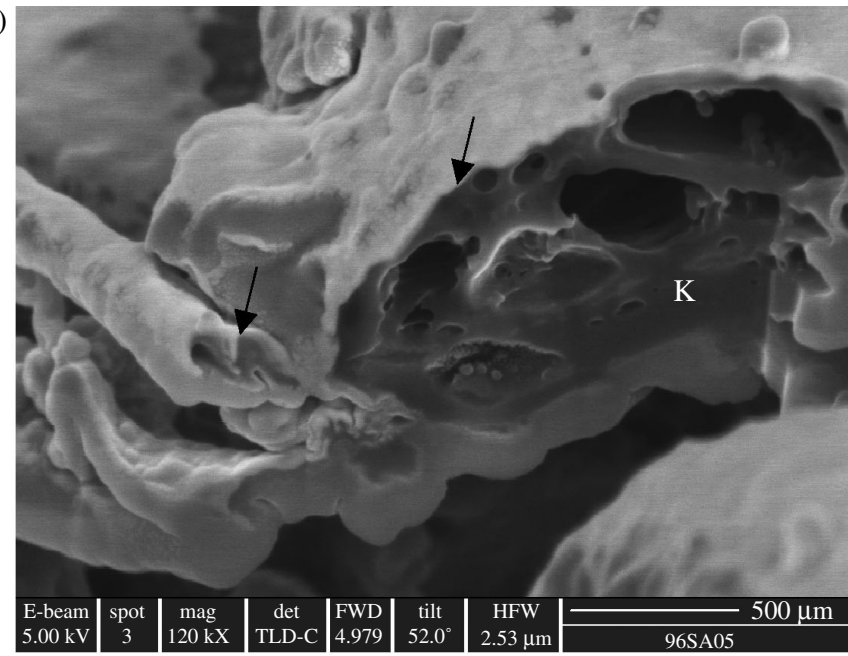

cps

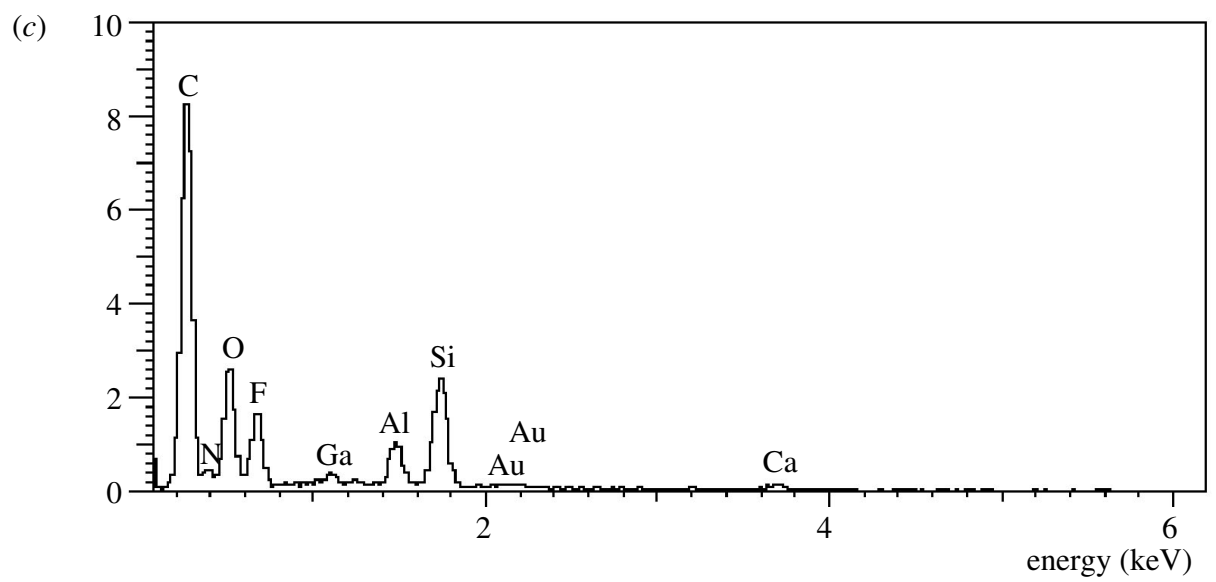

Figure 10. FIB section across a ropy portion of the mat. (a) Secondary image showing the location of the FIB section (arrow). (b) Ion beam image of the section surface documenting the alveolar-like structure of the degraded organic matter (amorphous kerogen, K) in the interior of the mat (cf. kopara in modern calcareous lagoons, Défarge et al. 1994). The fineness of the silica coating in the top of the mat is observable in this image (arrows). (c) EDX analysis illustrating the strong carbon peak detected in the amorphous kerogen below the surface of the mat.

or portions of the filamentous biofilm that are overturned (figures $6 a$ and $7 a, d$ ).

(ii) Colonial and biofilm characteristics

Association with a number of other organisms of the same species. The filamentous film consists of many individuals, all exhibiting the same morphological characteristics (figure $6 a$ ). The small group of rod/vibroid-shaped individuals likewise have the same morphology (figure $6 e$ ).

Association with microbially produced polymer (EPS). The filmy material in which the filaments and $\mathrm{rod} /$ vibroid-shaped individuals are embedded is interpreted as extracellular polymeric substance that is typically produced by microbial colonies growing as a biofilm on a surface (Charaklis \& Wilderer 1989). The heterogeneous textures (ropy, smooth, granular or containing holes; figures $6 b, c, 8 a, b, 9 c, 10 a$ and $11 a$ ) of the EPS are also typical of microbially produced polymer. The texture of the granular part of the film is due to the formation of intraformational acicular microcrystals less than $200 \mathrm{~nm}$ (probably aragonite). The small colony of rod/vibroid-shaped structures is embedded in a smooth film on top of a granulartextured film (figure $6 e$ ).
Formation of biofilms. The combination offilamentous individuals and the thick, heterogeneously textured film together represents a biofilm (figure 5), as does the consortium of rod/vibroid-shaped cells (figure $6 e$ ).

\section{(iii) Chemical and isotopic composition,}

\section{Raman spectroscopy}

Carbonaceous composition. Light element EDX analyses of individual filaments, and from within the amorphous material beneath the silicified surface of the mat, document the presence of C (figure $8 c, d, 10$ and 11b).

Isotopic composition. Although the low bulk carbon content of the subsample of 96SA05 requires that the $-22.7 \pm 0.1 \%$ o carbon isotope ratio be regarded with caution $^{1}$, this value is nevertheless consistent with fractionation by biological processes (de Ronde \& Ebbesen 1996). However, this measurement is confirmed by the second measurement of - $26.8 \pm$ $0.1 \%$, made on another sample from the same exposure in which the carbon contents were higher $(0.07 \mathrm{wt} \%)$. These results are consistent with the identification of carbonaceous microbial colonies and mats in the sample studied here. 

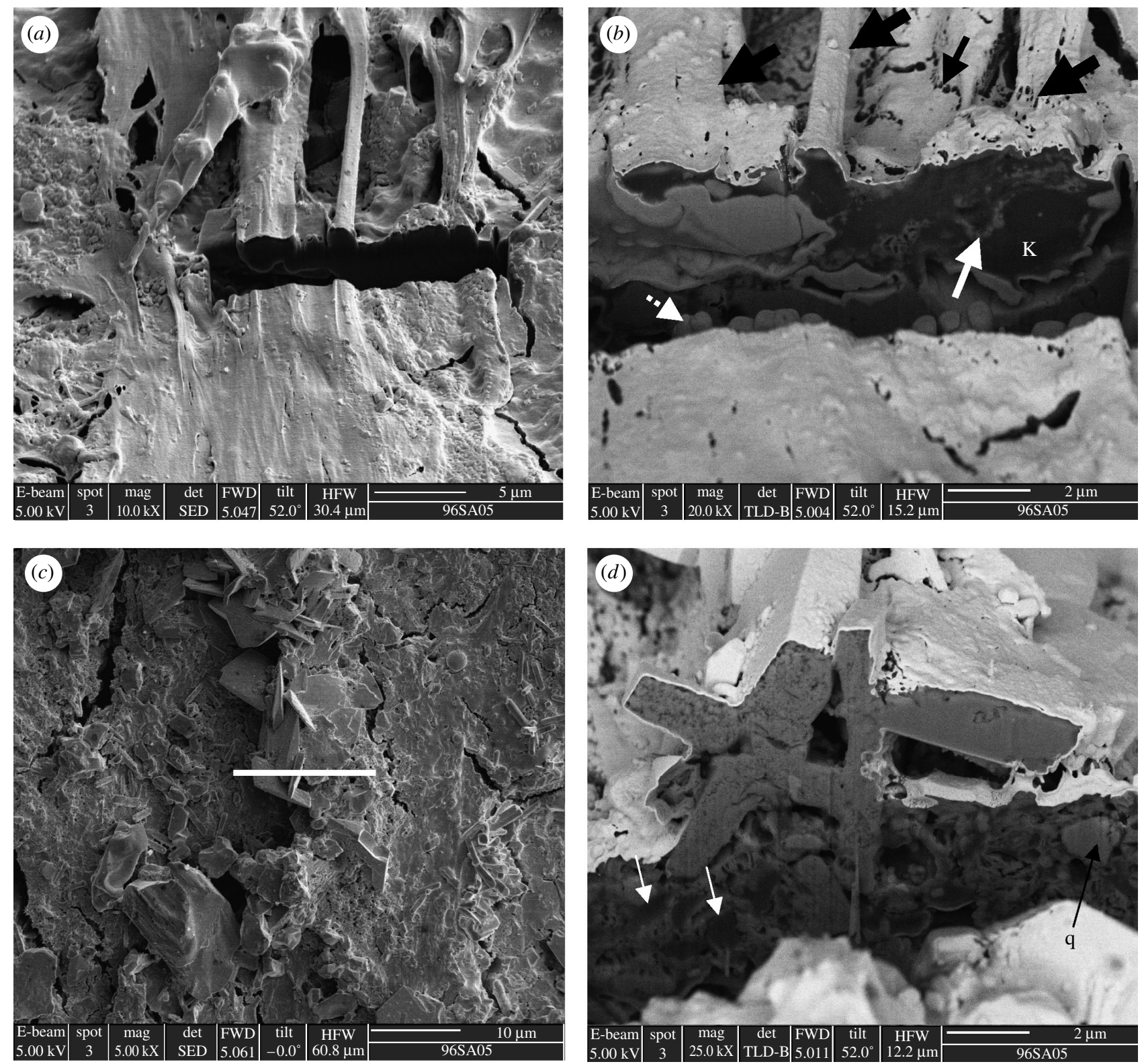

Figure 11. FIB-cut sections across different parts of the microbial mat. ( $a$ and $b$ ) show a cut across a portion of the mat that is not coated with evaporite minerals. (a) A secondary electron image of the smooth to ropy surface of this portion of the mat, showing the location of the FIB cut. (b) A backscattered image of the FIB section. Although bundles of filaments and individual filaments (fat black arrows) have been well-preserved on the surface of the mat by a thin layer of silica, individual filaments do not appear to have been preserved within the body of the mat. Instead, the kerogen (K, dark in appearance in this backscattered image, i.e. low z) is amorphous. Note the thin intervening layers of authigenic crystallites within the body of the mat (white arrow). The 'toe'-like structures below the mat (dotted white arrow) are an artefact of the ion beam sputtering, as are the holes in the high reflectance surface of the Au-coated mat in (small black arrow). ( $c$ and $d$ ) FIB section across an evaporite mineral encrusted portion of the mat. (c) Secondary electron image showing the location of the FIB section (white line). (d) In this backscattered image, the evaporite encrusted mat exhibits extreme complexity in its vertical structure. Dark amorphous masses of kerogen (white arrows) are indiscriminated interspersed with evaporite crystallites within the body of the mats. Note the quartz crystal (q) 'floating within the mineralized kerogen matrix'.

Raman spectroscopy. The Raman spectral analyses of the amorphous matter beneath the silicified surface of the mat show that it is carbonaceous, i.e. kerogen and that, moreover, the kerogen is mature since both the $\mathrm{D}$ and the $\mathrm{G}$ peaks are present (figure 4).

\section{(iv) Biogenic probability}

Combining the morphological, colonial, biofilm and compositional data, we believe that the probability of a biological origin for the $3475 \pm 5-3334 \pm 3 \mathrm{Myr}$ Barberton filamentous and rod/vibroid-shaped structures is extremely strong. To date, there are no known organic and/or mineralogical abiogenic structures (cf. Garcia-Ruiz et al. 2003) that exhibit the totality of characteristics demonstrated by the biofilms of filamentous and rod/vibroid-shaped organisms documented here.

Recent studies on carbon of abiogenic origin with isotopic signatures (-12\%; Van Zuilen et al. 2002), similar to those produced by certain bacteria, demonstrate the necessity of interpreting carbon isotope data with caution, and it could be hypothesized that both the 
organic $\mathrm{C}$ and the $\mathrm{C}$ isotopic signal measured in the Josefsdal Chert may be of abiogenic, hydrothermal origin, since there is an evidence for syn- to postdepositional crustal fluid influence (de Ronde et al. 1991). However, the chemical and the isotopic signatures in this chert sample do not occur in isolation. They are associated with carbonaceous films or mats consisting of filamentous and rod- to vibroid-shaped structures of probable microbial origin that formed in a neutral to a reducing environment. This is a strong argument for a biogenic interpretation of the $\mathrm{C}$ isotope signal.

\section{(c) Interaction of micro-organisms with the local environment}

Interaction of the biofilms with their immediate environment is demonstrated by: (i) the intergrowth of the filaments with the underlying sediment particles (figure $7 a$ ) and the incorporation of large underlying particles, such as spherulites (not shown) within the film; (ii) the incorporation of both detrital ('floating particles') and authigenically precipitated sediment particles within the film (figures $6 c, d, 7 b$ and $11 ; \mathrm{NB}$, the angular nature of the quartz particles indicates that they must have been derived from a local source); (iii) the response of the filaments and the biofilm to flowing water (i.e. filament orientation, overturning of portions of the biofilm, the mechanical tearing of the film (figures 5, $6 a, c, 8 a$ and $9 c, d$ ), and the change of $c a$ $40^{\circ}$ in the direction of the filaments in the uppermost layers of the mat (figure 5) suggesting a probable change in the orientation of water flow); (iv) the desiccation of the filamentous mat and the precipitation of evaporite minerals within its surface (figures $6 c, d$ and $11 d$ ) and (v) the rapid silicification of the mat as indicated by the turgid shapes of the microorganisms demonstrating that they were alive when fossilized (figures $6 e, f, 7 c, d$ and $8 b$ ).

\section{(d) In situ formation}

There are numerous indications that the filamentous mat-like structure and laterally associated granular crust (mineralized kerogen) must have formed in situ on the original sediment bedding plane surface and do not represent secondary material infilling a bedding parallel fracture:

(i) The mat occurs on top of a black layer that is partially overlain by a layer of greenish-white chert, and is therefore bedding parallel (NB, the continuous tops of the black layers probably represent short periods of interrupted sedimentation). It could be argued that there was a fortuitous bedding parallel crack in which a recent biofilm formed, but the arguments that follow show that this is not the case.

(ii) The filaments at the base of the mat are intergrown with the underlying particles (figure $7 a$ ) and the mat incorporates and grows around larger underlying particles figures $7 b$ and $11 d)$.

(iii) The filaments were observed by SEM embedded in the diagenetic quartz matrix in both unetched and etched thin section (figure $7 c, d$ ), thus indicating that they clearly predate the formation of the quartz.

(iv) Volcanic detritus, quartz grains and evaporitic minerals typical of the environment of deposition of the Early Mid-Archaean sediments are embedded within different mat layers indicating alternating cycles of mat formation, trapping of detrital minerals and precipitation of evaporite minerals (figures $6 c, d, 7 b$ and $11 c, d$ ). This would not be expected if the mat grew in a crack.

(v) The mat evidently formed under flowing water, before desiccation and fossilization. Such a situation that included overturning of portions of the mat and a change in direction of flow (figure $9 c, d$ ), as well as physical tearing of the mat (figure $8 a$ ) indicates relatively strong flow conditions. This is not to be expected in a crack.

(vi) Raman spectroscopy of the carbonaceous mat shows that it consists of kerogen of a maturity that is consistent with the age and metamorphic grade of the host rock.

(vii) The filamentous mat described here does not exhibit characteristics typical of chasmolithic micro-organisms infiltrating a crack in a rock. Chasmolithic infiltration would have colonized both sides of the crack and would not have constructed the complex, vertical architecture observed in this mat.

(viii) The Plio-Pleistocene-Holocene environmental history of this part of South Africa is pluvial/semi-tropical rather than dry and evaporitic, thus a suite of evaporite minerals is unlikely to develop in association with chasmolithic communities that may infiltrate cracks in rocks in this geographical area.

(ix) The anions of the evaporite minerals have been replaced by fluorine, the source of which was probably hydrothermal fluids. No evidence of recent hydrothermal activity has been documented in this particular locality of the Barberton greenstone belt.

(x) FIB sectioning shows that the whole surface of the mat has been coated by a layer of silica, including the evaporite minerals embedded in its surface (figure $11 d$ ). It has been suggested that the halides could have been introduced during sample preparation, but the coating of silica and the evidence for the coetaneous formation of the mat and the crystals (some of the crystals exhibit truncated surfaces where they have formed in contact with the mat filaments, whereas other halide crystals are deeply embedded within the polymer surface of the mat) demonstrate that the halides were precipitated at the same time like mat formation and silicification.

\section{(e) Fossilization and post-depositional alteration} The turgid shapes of the filamentous micro-organisms at the surface of the mat and the rod/vibroid-shaped micro-organisms demonstrate that they were intact and 
possibly still alive when fossilized (figure $6 e, f$ ). Silicification must have been rapid in order to preserve the surface of the mat and the colony of rod/vibroids with such faithful detail (NB, experiments show that silicification can occur very rapidly, Westall et al. 1995; and even within a day, Toporski et al. 2001).

FIB sectioning of the mat showed that the organic matter within the body of the mat, rather than being preserved as individual filaments, had been degraded and that it often exhibited an alveolar-like structure reminiscent of kopara (degraded organic matter in mats formed in modern calcareous lagoonal environments by photosynthetic micro-organisms; Défarge et al. 1994). The contrast between the degraded interior of the mat and the extremely well-preserved exterior reinforces the rapidity of the silicification. According to TEM/SEM EDX analyses, the lower part of the mat appears to have been replaced by nanoscale calcium carbonate (micritized).

The difference between the superb morphological preservation of the silica-coated mat surface and the alveolar-like structure of the degraded organic matter within the body of the mat has interesting consequences for the preservation of microbial mats in general. It also explains why, in these Early Archaean chert formations, generic mat-like features, preserved as layers of carbonaceous matter, are relatively common (cf. Walsh 1992, 2004; Walsh \& Westall 2003), whereas as individual organisms have not been identified within the carbonaceous material of the mat layers. Walsh \& Westall (2003) noted that filamentous structures were more common in the intervening quartz-rich layers. Indeed, the thicker, $2.5 \mu \mathrm{m}$ diameter, filaments interpreted by Walsh (1992) as cyanobacterial filaments on the basis of their diameters, most likely represent bundles of thinner filaments (cf. figures $6 a, 7 c, d$ and $10 a)$.

The fact that the microbial structures are silicified by only a thin coating of silica on their outer surfaces suggests a change in environmental conditions with the rapid influx of fluids rich in silica, for instance, as in the submergence of the littoral zone below sea-level and/or the influx of hydrothermal fluids rich in silica. The sources of silica include evaporitic enrichment (de Ronde et al. 1997), enriched seawater from hydrothermal fluid input (de Wit et al. 1982; de Ronde et al. 1994; Knauth \& Lowe 2003) and pore-water enrichment from early diagenetic devitrification of the volcanic particles (cf. Orberger et al. 2006). The influence of a (pene)contemporaneous hydrothermal source is indicated by the rapid replacement of the evaporite-related minerals (anions) by fluorine-rich fluids and the oxidation of the pyrite crystals associated with the mat. It is interesting to note that the silicification of EPS and microbial biofilms and mats in modern hot-spring environments produce characteristics similar to those described here (e.g. Renaut et al. 1998; Konhauser et al. 2003).

Other effects of post-depositional alteration include: (i) the vertical pressure exerted by the weight of successive layers of sediments, as demonstrated by compaction, especially of the fine-grained layers (the spherulites, however, exhibit no evidence of compaction and were probably already, at least partially, devitrified and silicified before compaction took place), and a certain amount of stylolitization and (ii) the quartz-filled extension cracks reflecting extensive tectonic movements and the alteration of the remains of the phyllosilicate-replaced spherulites and volcanic shards to Cr-muscovite (fuchsite) is probably related to the overall burial metamorphism that affected the whole of the southern part of the Barberton greenstone belt (Kisch \& Nijman 2004).

\section{(f) Implications for organism type}

We hypothesize that the filamentous microbial mat was formed by photosynthesizing micro-organisms for the following reasons: (i) The morphology of the filaments, their mat-forming behaviour, the vertical architecture of the mat and its formation in a sunlightbathed environment are the typical characteristics of mats formed by modern photosynthesizing filamentous micro-organisms (Stolz 2000). (NB, modern microbial photosynthetic mats, such as those forming the stromatolites in Shark Bay, Western Australia, contain a significant component of anoxygenic photosynthesizing prokaryotes, e.g. Papineau et al. 2005). (ii) The carbon isotope signature (of strongly probably biogenic origin, as explained earlier) is consistent with that produced by photosynthetic micro-organisms (Reysenbach \& Cady 2001).

Geochemical studies indicate that the immediate environment of the mat was anoxic, since pseudomorph pyrite crystals are directly associated with the mat. This implies that, if photosynthesizing, the microorganisms must have been anoxygenic photosynthesizers. The carbon isotopes are also consistent with anoxygenic photosynthesis (Reysenbach \& Cady 2001). Anoxygenic photosynthesis requires the presence of hydrothermal or biogenic hydrogen sulphide (Imhoff 1995) or the presence of ferrous iron (Kappler \& Newman 2004), both of which would have been present at the time of the formation of the mat-like structure (de Ronde et al. 1994, 1997).

Considering their morphological characteristics and their intimate association with the underlying pyrite layers, we interpret the small colony of $\mathrm{rod} /$ vibroid-shaped micro-organisms as possible sulphate-reducing bacteria (SRB), which are often found in close association with anoxygenic photosynthetic organisms and which can catalyse the formation of pyrite (Donald \& Southam 1999). Sulphate, occurring in low levels in the Barberton Mid-Archaean ocean (de Ronde et al. 1997), would act as an electron acceptor and enrich for dissimilatory SRB. Likewise, the local environment could have furnished an abundant source of electron donors in the form of either hydrogen or hydrocarbons. Hydrogen would have been available as a result of both the liberation of the gas during serpentinization of the ultramafic rocks that were abundant in the Lower Onverwacht Group (i.e. stratigraphically below the chert horizon), as well by the alteration reactions of iron-containing minerals, that were also common in the area. Organic molecules could have been available from both hydrothermal abiogenic sources, e.g. methane (Foustoukos \& Seyfried 2004; Foustoukos et al. 2004), as well as from degraded biogenic 
organic matter, of which this study shows that there was an abundance both within the main body of the mat itself, as well as from the degradation of other micro-organisms buried in the subsurface sediments (compare with the degraded subsurface chemolithotrophs and buried possible anoxygenic phototrophs in similar-aged volcanoclastic sediments from the Pilbara; Westall et al. 2006).

Formation under evaporitic conditions indicates that these micro-organisms were halo-tolerant or halophilic (Kamekura 1998). Given the evidence that the mat was formed under flowing water in a subaerial environment, and the geochemical indications for flushing by hydrothermal fluids, it is possible that the filamentous mat is formed in the vicinity of a hydrothermal spring in the beach environment (cf. figure 9). This close association could imply that the organisms were at least thermo-tolerant. Such a hypothesis is also supported by the calculated high ambient seawater temperatures for that period $\left(40^{\circ} \mathrm{C}\right.$ by de Ronde et al. 1994 and possibly up to $55-80^{\circ} \mathrm{C}$ by Knauth \& Lowe 2003).

\section{(g) Implications for the UVenvironment of the early Earth}

Both the filamentous microbial mat and the rod/vibroid colony appeared to have been in a healthy state when fossilized, despite the evident periodic direct exposure to the atmosphere. As suggested by Cockell \& Raven (2004), coating by evaporite minerals can contribute to UV shielding; however, in their experiments, a thickness of at least $1 \mathrm{~mm}$ of evaporite minerals was required in order to protect the micro-organisms. Since the overall thickness of the filamentous mat ranges from 1 to $4 \mu \mathrm{m}$ and the thickness of the evaporite mineral layer at the surface of the mat is of the order of a few micrometres at most, it is unlikely that the evaporates played an important role in attenuating UV radiation penetration. Moreover, there are large areas of the mat that are not covered by evaporite minerals (compare figures $8 a$ and $11 c$ ) and the filaments in the non-coated areas exhibit a very healthy appearance (figures $6 a, c, f$ and $8 b$ ).

Since the microbial mat evidently lived healthily in a more exposed situation, either the UV radiation environment at the surface of the Earth must have been more clement than has been previously modelled, and/or the repair processes/biological screening compounds could efficiently cope with high-UV fluxes. Despite the lack of $\mathrm{O}_{3}$ in this anoxic time-period, it has been suggested that other compounds in the early atmosphere could have been important UV absorbers, notably a proposed thin organic haze produced by photolysis of $\mathrm{CH}_{4}$ (Pavlov et al. 2001; Kasting 2005). Carbon isotope analyses indicate that methanogenic micro-organisms probably inhabited the Early MidArchaean Earth (see review in Westall \& Southam 2006), thus providing a source for the $\mathrm{CH}_{4}$, an important greenhouse gas. However, as noted by Kasting (2005), the organic smog could not have been optically too thick otherwise it would have had a negative effect on temperatures at the surface of the Earth. The existence of evaporitic conditions associated with the exposed microbial mat demonstrates that surface temperatures must have been at least moderately warm. Thus, the organic smog must have been optically thin at the same time as providing the UV protection necessary for the early photic zone micro-organisms.

\section{CONCLUSIONS}

We have demonstrated that a multidisciplinary approach to the study of traces of ancient life, from the macroscopic to the microscopic and elemental level, is crucial to the reliable interpretation of the biogenicity of very ancient structures. We have thus demonstrated that the combined morphological and chemical characteristics of a filamentous mat and associated colony of rod/vibroid micro-organisms that formed on the surface of $3.47-3.33 \mathrm{Ga}$ littoral sediments in the Barberton greenstone belt are identical to those known for modern bacteria. Moreover, the interactions of these structures with, and responses to, their immediate environment are also similar to those of modern microbial mats and colonies. An alternative, abiogenic interpretation for these structures is unlikely because an abiogenic organomineral neither shows the totality of morphological and chemical (including isotopic) characteristics exhibited by microbial colonies, biofilms and mats nor would it show the complex environmental responses documented in this study. We therefore conclude that the probability of biogenicity of the filamentous mat-like structure and the rod to vibroid-shaped structures is strong, and that they represent the fossilized remains of mat-forming micro-organisms, which probably included anoxygenic photosynthesizers and possibly SRBs. Fossilization occurred by micritization of the degraded organic matter in the body of the mat and by rapid silicification of its surface (including the colony of rod/vibroid-shaped micro-organisms). Later infiltration of these micro-organisms into a pre-existing crack can be discounted for many reasons, including the maturity of the kerogen, the direct interactions exhibited by the micro-structures with their volcanosedimentary environment, the formation of the mat under flowing water and its subsequent exposure to evaporitic conditions and silicification. These fossilized remains have therefore the same age as their host rock, i.e. they are 3475 $\pm 5-3334 \pm 3$ Myr-old. The filamentous mat thus represents the oldest known example of life in a subaerial littoral environment.

This observation of a microbial mat formed in an evaporitic, littoral environment places strong constraints on the UV environment of the early Earth and its influence on life on the photic zone. The UV environment was probably relatively clement due to the presence of an organic haze as well as other UV-absorbing compounds in the atmosphere. Furthermore, a combination of factors including efficient repair of UV damage and the presence of UV-screening compounds in the organisms would have served as protection for the micro-organisms.

The methodological approach used in the determination of biogenicity and in situ formation of the Josefsdal Chert microbial mat can, thus, serve as a model for future investigations of this type. Our results 
therefore have an important impact on the present polemical situation regarding ancient biosignatures, demonstrating clearly not only the existence of microorganisms in the Early Mid-Archaean period, but also providing detailed information regarding the probable nature of the micro-organisms and their habitat and interactions with their environment.

M. de Wit, W. Nijman, S. de Vries are thanked for helpful discussions in the field. The critical comments of anonymous reviewers and N. Hinman, A. Brack and P. Labrot greatly helped improving the manuscript. We thank D. Marchesini for field assistance; A. Richard for FEG-SEM assistance; O. Rouer for help with the microprobe analyses; F. Tatti and B. Cavalazzi for assistance with the FIB (University of Modena); T. Cantalupo for assistance with figure 1 and F. Orange for assistance with figure $2 a$; and D. McKay, the LPI, Houston, the CNRS and CNES for funding.

\section{ENDNOTE}

'This sample was one of 16 different Barberton rock samples (age range $3.472-3.2 \mathrm{Ga}$ ) analysed for their $\delta^{13} \mathrm{C}$ values. Most of the samples contained very little carbon, ranging from 0.01 to $0.16 \mathrm{wt} \%$. Between 14 and $158 \mu \mathrm{g}$ of $\mathrm{C}$ were extracted from the samples for analysis. Three blanks runs were also done, which had C concentrations of $1.3-8 \mu \mathrm{g}$ and $\delta^{13} \mathrm{C}$ values between -21.8 and $-22.4 \%$. Samples with less than 10 times background (approx. $80 \mu \mathrm{g}$ ) were considered likely to need a correction for the estimated blank value, and those with less than five times background (approx. $40 \mu \mathrm{m}$ ) were initially ignored as being unreliable. Thus, corrections assuming a blank contribution of $6 \mu \mathrm{g} \mathrm{C}$ with a $\delta^{13} \mathrm{C}$ of $-22 \%$ were made to the samples having between 40 and $80 \mu \mathrm{g} \mathrm{C}$. The errors of these analyses are probably around $\pm 0.5 \%$. The sample analysed in this study contained $16 \mu \mathrm{g}$ of $\mathrm{C}$ and using the above criteria, should be considered unreliable. The $\mathrm{C}$ may represent rock $\mathrm{C}$ or there could be traces of contamination during the rock preparation or adsorbed on the rock powder, although this is not likely as acid $(\mathrm{HCl})$ digestion indicated no carbonate $\mathrm{C}$ and the sample was prepared in such as way as to eliminate the possibility of contamination. Moreover, the result is consistent with those of other, similar cherts containing reliable concentrations of $\mathrm{C}$ and measured at the same time, e.g. sample 96-SA-01 which had $48 \mu \mathrm{g}$ of $\mathrm{C}$ and a corrected $\delta^{13} \mathrm{C}$ value of $-27.0 \%$, and others with $>40 \mathrm{mg}$ of $\mathrm{C}$ with $\delta^{13} \mathrm{C}$ having values between -24.1 and $-28.3 \%$ (i.e. similar to cherts analysed by de Ronde \& Ebbesen 1996).

\section{REFERENCES}

Allwood, A. C., Walter, M. R., Kamber, B. S. \& Burch, I.W. In press. Stromatolite reef from the Early Archaean era of Australia, Nature, 441, 714-719.

Armstrong, R. A., Compston, W., de Wit, M. J. \& Williams, I. S. 1990 The stratigraphy of the 3.5-3.2 Ga Barberton greenstone belt revisited: a single zircon microprobe study. Earth Planet. Sci. Lett. 101, 90-106. (doi:10.1016/0012821X(90)90127-J)

Awramik, S. M. \& Sprinkle, J. 1999 Proterozoic stromatolites: the first marine evolutionary biota. Historical Biol. 13, 241-253.

Brasier, M. D., Green, O. R., Jephcoat, A. P., Kleppe, A. K., van Kranendonk, M., Lindsay, J. F., Steele, A. \& Grassineau, N. 2002 Questioning the evidence for Earth's oldest fossils. Nature 416, 76-81. (doi:10.1038/416076a)

Buick, R. 1990 Microfossil recognition in Archean rocks: an appraisal of spheroids and filaments from a 3500 m.y. old chert-barite unit at North Pole, Western Australia. Palaios 5, 441-459.
Byerly, G. R., Lowe, D. R. \& Walsh, M. M. 1986 Stromatolites from the 3300-3500 Myr Swaziland Supergroup, Barberton Mountain Land, South Africa. Nature 319, 489-491. (doi:10.1038/319489a0)

Byerly, G. R., Kröner, A., Lowe, D. R., Todt, W. \& Walsh, M. M. 1996 Prolonged magmatism and time constraints for sediment deposition in the early Archaean Barberton greenstone belt: evidence from the Upper Onverwacht and Fig Tree groups. Precambrian. Res. 78, 125-138. (doi:10. 1016/0301-9268(95)00073-9)

Cady, S. L. \& Farmer, J. D. 1996 Fossilization processes in siliceous thermal springs: trends in preservation along the thermal gradient. In Evolution of hydrothermal ecosystems on Earth (and Mars) (ed. G. R. Bock \& J. A. Goodie) Ciba Symposium 202, pp. 150-173. Chichester, UK: Wiley.

Catling, D., Zahnle, K. \& McKay, C. P. 2001 Biogenic methane, hydrogen escape, and the irreversible oxidation of early Earth. Science 293, 839-843. (doi:10.1126/ science.1061976)

Canuto, V. M., Augustsson, J. S., Levine, T. R. \& Imhoff, C. L. 1982 UV radiation from the young sun and oxygen and ozone levels in the prebiological palaeoatmosphere. Nature 296, 816-820. (doi:10.1038/296816a0)

Charaklis, W. G. \& Wilderer, P. A. (eds) 1989 Structure and function of biofilms. Chichester, UK: Wiley.

Cockell, C. S. 1999 Carbon biochemistry and the ultraviolet radiation environments of $\mathrm{F} \mathrm{G}$ and $\mathrm{K}$ main sequence stars. Icarus 141, 399-407. (doi:10.1006/icar.1999.6167)

Cockell, C. S. \& Raven, J. A. 2004 Zones of photosynthetic potential on Mars and the early Earth. Icarus 169, 300-310. (doi:10.1016/j.icarus.2003.12.024)

Cockell, C. S., Catling, D. C., Davs, W. I., Snook, K., Kepner, R. L., Lee, P. \& McKay, C. P. 2000 The ultraviolet environment of Mars: biological implications past present and future. Icarus 146, 343-359. (doi:10. 1006/icar.2000.6393)

Córdoba-Jabonero, C., Lara, L. M., Mancho, A. M., Márquez, A. \& Rodrigo, R. 2003 Solar ultraviolet transfer in the martian atmosphere: biological and geological applications. Planet. Space Sci. 51, 399-410. (doi:10. 1016/S0032-0633(03)00023-0)

Défarge, C., Trichet, J., Maurin, A. \& Hucher, M. 1994 Kopara in Polynesian atolls: Early stages of formation of calcareous stromatolites. Sediment. Geol. 89, 9-23. (doi:10.1016/0037-0738(94)90080-9)

de Ronde, C. E. J. \& Ebbesen, T. 19963.2 billion years of organic compound formation near seafloor hot springs. Geology 24, 791-794. (doi:10.1130/0091-7613(1996) $024<0791: \mathrm{BYOOCF}>2.3 . \mathrm{CO} ; 2)$

de Ronde, C. E. J., Hall, C. M., York, D. \& Spooner, E. T. C. 1991 Laser step-heating ${ }^{40} \mathrm{Ar} /{ }^{39} \mathrm{Ar}$ age spectra from early Archean ( $3.5 \mathrm{Ga}$ ) Barberton greenstone belt sediments: a technique for detecting cryptic tectono-thermal events. Geochim. Cosmochim. Acta 55, 1933-1951. (doi:10.1016/ 0016-7037(91)90034-3)

de Ronde, C. E. J., de Wit, M. T. \& Spooner, E. T. C. 1994 Early Archean ( $>3.2 \mathrm{Ga}$ ) Fe-oxide-rich, hydrothermal discharge vents in the Barberton greenstone belt, South Africa. Geol. Soc. Am. Bull. 196, 86-104. (doi:10.1130/ 0016-7606(1994)106<0086:EAGFOR>2.3.CO;2)

de Ronde, C. E. J., Channer, D. M. DeR. ., Faure, K., Bray, C. J. \& Spooner, E. T. C. 1997 Fluid chemistry of Archean seafloor hydrothermal vents; implications for the composition of circa $3.2 \mathrm{Ga}$ seawater. Geochim. Cosmochim. Acta 61, 4025-4042. (doi:10.1016/S0016-7037(97)00205-6)

de Wit, M. J., Hart, R. A., Martin, A. \& Abbott, P. 1982 Archaean abiogenic and probable biogenic structures 
associated with hydrothermal vent systems and regional metasomatism, with implications for greenstone belt studies. Econ. Geol. 77, 1783-1802.

Donald, R. \& Southam, G. 1999 Low temperature anaerobic bacterial diagenesis of ferrous monosulfide to pyrite. Geochim. Cosmochim. Acta 63, 2019-2023. (doi:10.1016/ S0016-7037(99)00140-4)

Foustoukos, D. I. \& Seyfried Jr, W. E. 2004 Hydrocarbons in hydrothermal vent fluids: the role of chromium-bearing catalysts. Science 304, 1002-1005. (doi:10.1126/science. 1096033)

Foustoukos, D.I., Qi, F., Seyfied Jr, W.E. 2004. Abiotic synthesis of methane under alkaline hydrothermal conditions: the effects of $\mathrm{pH}$ in heterogeneous catalysis. Eos, Trans. AGU, 85, Fall Meet. Suppl. Abstract B13A-0212.

Furnes, H., Banerjee, N. R., Muehlenbachs, K., Staudigel, H. \& de Wit, M. 2004 Early life recorded in Archean pillow lavas. Science 304, 578-581. (doi:10.1126/science. 1095858)

Garcia-Pichel, F., Mechling, M. \& Castenholz, R. W. 1994 Diel micgrations of micro-oirganisms within a benthic hypersaline mat community. Appl. Environ. Microbiol. 60, 1500-1511.

Garcia-Ruiz, J. M., Hyde, S. T., Carnerup, A. M., Christy, A. G., van Krankendonk, M. J. \& Welham, N. J. 2003 Selfassembled silica-carbonate structures and detection of ancient microfossils. Science 302, 1194-1197. (doi:10. 1126/science.1090163)

Gough, D. O. 1981 Solar interior structure and luminosity variations. Sol. Phys. 74, 21-34. (doi:10.1007/BF00 151270)

Grassineau, N.V. In press. High precision EA-IRMS analysis of $\mathrm{S}$ and $\mathrm{C}$ isotopes in geological materials. In Frontiers in analytical chemistry - an IGC 2004 perspective (Ed. R.S. Harmon and R. Vannucci), Appl. Geochem.

Guerrero, R., Piqueras, M. \& Berlonga, M. 2002 Microbial mats and the search for minimal ecosystems. Int. Microbiol. 5, 177-188. (doi:10.1007/s10123-002-0093-9)

Handley, K. M., Campbell, K. A., Mountain, B. W. \& Browne, P. R. L. 2005 Abiotic-biotic controls on the origin and development of spicular sinter: in situ growth experiments, Champagne Pool, Waiotapu, New Zealand. Geobiology 3, 93-114. (doi:10.1111/j.1472-4669.2005. 00046.x)

Hessler, A. M., Lowe, D. R., Jones, R. L. \& Bird, D. K. 2004 A lower limit for atmospheric carbon dioxide levels 3.2 billion years ago. Nature 428, 736-738. (doi:10.1038/ nature02471)

Hofmann, H. J., Grey, K., Hickman, A. H. \& Thorpe, R. I. 1999 Origin of $3.45 \mathrm{Ga}$ coniform stromatolites in Warrawoona Group, Western Australia. Geol. Soc. Am. Bull. 111， 1256. (doi:10.1130/0016-7606(1999)111< 1256:OOGCSI > 2.3.CO;2)

Imhoff, J. F. 1995 Taxonomy and physiology of phototrophic purple bacteria and green sulfur bacteria. In Anoxygenic photosynthetic bacteria (ed. R. E. Blakenship, M. T. Madigan \& C. E. Bauer), pp. 1-15. Dordrecht, The Netherlands: Kluwer.

Kamekura, M. 1998 Diversity of extremely halophilic bacteria. Extremophiles 2, 289-295. (doi:10.1007/ s007920050071)

Kappler, A. \& Newman, D. K. 2004 Formation of Fe(III)minerals by $\mathrm{Fe}(\mathrm{II})$-oxidizing photoautotrophic bacteria. Geochim. Cosmochim. Acta 68, 1217. (doi:10.1016/j.gca. 2003.09.006)

Kasting, J. F. 1993 Earth's early atmosphere. Science 259, 920-926.

Kasting, J. F. 2005 Methane and climate during the Precambrian era. Precambrian Res. 137, 119-129. (doi:10.1016/j.precamres.2005.03.002)
Kasting, J. F. \& Brown, L. L. 1998 Setting the stage: the early atmosphere as a source of biogenic compounds. In The molecular origins of life: assembling the pieces of the puzzle (ed. A. Brack), pp. 35-56. New York, NY: Cambridge University Press.

Kisch, H. J. \& Nijman, W. 2004 Metamorphic grade from the K-micas in the metasediments from the Pilbara and Barberton greenstone belts. In Field forum on processes on the early Earth, Kaapvaal Craton, South Africa (ed. W. U. Reimold \& A. Hofmann), pp. 47-48. Johannesburg, South Africa: University of Witwatersrand.

Konhauser, K. O., Jones, B., Reysenbach, A.-L. \& Renaut, R. W. 2003 Hot spring sinters: keys to understanding Earth's earliest life forms. Can. F. Earth Sci. 40, 1713-1724. (doi:10.1139/e03-059)

Knauth, P. \& Lowe, D. R. 2003 High Archean climatic temperature inferred from oxygen isotope geochemistry of cherts in the $3.5 \mathrm{Ga}$ Swaziland Supergroup, South Africa. Geol. Soc. Am. Bull. 115, 566-580. (doi:10.1130/00167606(2003) $115<0566$ :HACTIF $>2.0$.CO;2)

Lowe, D. R. 1980 Stromatolites 3,400-Myr old from the Archean of Western Australia. Nature 284, 441-443. (doi: $10.1038 / 284441 \mathrm{a} 0$ )

Lowe, D. R. 1994 Abiological origin of described stromatolites older than 3.2 Ga. Geology 22, 287-390.

Lowe, D. R. \& Byerly, G. R. (eds) 1999 Geologic evolution of the Barberton greenstone belt, South Africa. Geological Society of America Special Paper 329.

Matthews, D. E. \& Hayes, J. M. 1978 Isotope-ratiomonitoring gas chromatography-mass spectrometry. Anal. Chem. 50, 1465-1473. (doi:10.1021/ac50033a022)

Mel'nik, Y. P. 1982 Precambrian banded iron formations. New York, NY: Elsevier.

Mountain, B. W., Benning, L. G. \& Boerema, J. A. 2003 Experimental studies on New Zealand hot spring sinters: rates of growth and textural development. Can. F. Earth Sci. 40, 1643-1667. (doi:10.1139/e03-068)

Newman, M. J. \& Rood, R. T. 1977 Implications of solar evolution for the Earth's early atmosphere. Science 198, 1035-1037.

Orberger, B., Rouchon, V., Westall, F., de Vries, S. T., Wagner, C. \& Pinti, D. L. 2006 Protoliths and microenvironments of some Archean Cherts (Pilbara, Australia). In Processes on the Early Earth (ed. W. U. Reimold \& R. Gibson). Geological Society of America Special Paper, 405, 132-154.

Papineau, D., Walker, J. J., Mojzsis, S. J. \& Pace, N. R. 2005 Composition and structure of microbial communities from stromatolites of Hamelin Pool, Shark Bay, Western Australia. Appl. Environ. Microbial. 71, 4822-4832. (doi:10.1128/AEM.71.8.4822-4832.2005)

Paris, I. 1985 The geology of the farms Josefsdal, Dunbar and Diepgezet in the southern part of the Baberton greenstone belt. Unpublished Ph.D. Thesis, University of Witwaterstrand.

Pavlov, A. A., Kasting, J. F., Brown, L. L., Rages, K. A. \& Freedman, R. 2001 Greenhouse warming by $\mathrm{CH} 4$ in the atmosphere of early Earth. f. Geophys. Res. 105, $11900-11981$.

Renaut, R. W., Jones, B. \& Rosen, M. R. 1998 Influence of microbes on the fabrics of siliceous microbialites: a case study from Ohaaki Pool hot-spring system, North Island, New Zealand. F. Sedimentol. Res. 68, 413-434.

Reysenbach, A.-L. \& Cady, S. L. 2001 Microbiology of ancient and modern hydrothermal systems. Trends Microbiol. 9, 79-86. (doi:10.1016/S0966-842X(00)01921-1)

Ribas, I., Guinan, E. F., Güdel, M. \& Audard, M. 2005 Evolution of the solar activity over time and effects on 
planetary atmospheres. I. High energy irradiances (1-1700 A). Astrophys. F. 622, 680-691. (doi:10.1086/ 427977)

Rontó, G., Bérces, A., Lammer, H., Cockell, C. S., MolinaCuberos, G. J., Patel, M. R. \& Selsis, F. 2003 Solar UV irradiation conditions on the surface of Mars. Photochem. Photobiol. 77, 34-40.

Rye, R., Kuo, P. H. \& Holland, H. D. 1995 Atmospheric carbon dioxide concentrations before 2.2 billion years ago. Nature 378, 603-605. (doi:10.1038/378603a0)

Sagan, C. \& Chyba, C. 1997 The early faint young sun paradox: organic shielding of ultraviolet-labile greenhouse gases. Science 276, 1217-1221. (doi:10.1126/science.276. 5316.1217)

Schopf, J. W. 1993 Microfossils of the Early Archean Apex Chert: new evidence of the antiquity of life. Science 260, 640-646.

Stolz, J. F. 2000 Structure of microbial mats and biofilms. In Microbial mats (ed. R. E. Riding \& S. M. Awramik), pp. 1-8. Berlin, Germany: Springer.

Tice, M. \& Lowe, D. R. 2004 Photosynthetic microbial mats in the 3,416-Myr-old ocean. Nature 431, 549-552. (doi:10.1038/nature02888)

Toporski, J. K. W., Westall, F., Thomas-Keprta, K. A., Steele, A. \& Mckay, D. S. 2001 The simulated silicification of bacteria-new clues to the modes and timing of bacterial preservation and implications for the search for extraterrestrial microfossils. Astrobiology 2, 1-25. (doi:10.1089/ 153110702753621312)

Vai, G. B. \& Ricci Lucchi, F. 1977 Algal crusts, autochthonous and clastic gypsum in a cannibalistic evaporitic basin: a case history from the Messinian of Northern Appenines. Sedimentology 24, 211-244. (doi:10.1111/ j.1365-3091.1977.tb00255.x)

Van Zuilen, M., Lepland, A. \& Arrhenius, G. 2002 Reassessing the evidence for the earliest traces of life. Nature 418, 627-630. (doi:10.1038/nature00934)

Walker, J. C., Klein, C., Schidlowski, M., Schopf, J. W., Stevenson, D. J. \& Walter, M. R. 1983 Environmental evolution of the archean-early proterozoic earth. In Earth's earliest biosphere (ed. J. W. Shopf), pp. 260-290. Princeton, NJ: Princeton University Press.

Walsh, M. M. 1992 Microfossils and possible microfossils from the Early Archean Onverwacht Group, Barberton Mountain Land, South Africa. Precambrian Res. 54, 271-293. (doi:10.1016/0301-9268(92)90074-X)
Walsh, M. M. 2004 Evaluation of early Archean volcanoclastic and volcanic flow rocks as possible sites for carbonaceous fossil microbes. Astrobiology 4, 429-437. (doi:10.1089/ast.2004.4.429)

Walsh, W. W. \& Westall, F. 2003 Archean biofilms preserved in the Swaziland Supergroup, South Africa. In Fossil and recent biofilms (ed. W. E. Krumbein et al.), pp. 307-315. Amsterdam, The Netherlands: Kluwer.

Walter, M. R., Buick, R. \& Dunlop, J. S. R. 1980 Stromatolites 3,400-3,500 Myr old from the North Pole area, Western Australia. Nature 284, 443-445. (doi:10. $1038 / 284443 \mathrm{a} 0$ )

Westall, F. 2004 Early life on earth: the ancient fossil record. In Astrobiology: future perspectives (ed. P. Ehrenfreund), pp. 287-316. Dordrecht, The Netherlands: Kluwer.

Westall, F. 2005 Life on the early Earth: a sedimentary view. Science 308, 366-367. (doi:10.1126/science.1107227)

Westall, F. \& Southam, G. 2006 Early life on Earth. In Archean geodynamics and environments (ed. K. Benn, J.-C. Mareschal \& K. C. Condie) AGU Geophys. Monogr. 164, 283-304.

Westall, F., Boni, L. \& Guerzoni, M. E. 1995 The experimental silicification of microbes. Palaeontology 38, 495-528.

Westall, F., De Wit, M. J., Dann, J., Van Der Gaast, S., de Ronde, C. E. J. \& Gerneke, D. 2001 Early Archaean fossil bacteria and biofilms in hydrothermally-influenced, shallow water sediments, Barberton greenstone belt, South Africa. Precambrian Res. 106, 93-116. (doi:10. 1016/S0301-9268(00)00127-3) Figs 4ab,9ab.

Westall, F., Brack, A., Barbier, B., Bertrand, M. \& Chabin, A. 2002 Early Earth and early life: an extreme environment and extremophiles-application in the search for life on Mars. ESA Spec. Pub. 1131-1136.

Westall, F., Orberger, O., Rouchon, V., Rouzaud, J.-N. \& Wright, I. 2004 On the identification of Early Archaean microfossils in cherts from Barberton and the Pilbara. In Field forum on processes on the early Earth, Kaapvaal Craton, South Africa (ed. W. U. Reimold \& A. Hofmann), pp. 94-97. Johannesburg, South Africa: University of Witwatersrand.

Westall, F. et al. 2006 The 3.466 Ga Kitty's Gap Chert, an Early Archaean microbial ecosystem. In Processes on the early Earth (ed. W. U. Reimold \& R. Gibson). Geological Society America Special Paper, 405, 105-131.

Zahnle, K. J. \& Walker, J. C. G. 1982 The evolution of solar ultraviolet luminosity. Rev. Geophys. Space Phys. 20, 280-292. 


\section{NOTICE OF CORRECTION}

This article is now presented in its correct form.

A detailed erratum will appear at the end of the volume.

11 October 2006 